Article

\title{
Exploring the Diversity and Biotechnological Potential of Cultured and Uncultured Coral-Associated Bacteria
}

\author{
Caren Leite Spindola Vilela ${ }^{1}$, Helena Dias Müller Villela ${ }^{1,2}$, Caio Tavora Coelho da Costa Rachid ${ }^{1}$, \\ Flávia Lima do Carmo ${ }^{1}$, Alane Beatriz Vermelho ${ }^{1}$ and Raquel Silva Peixoto ${ }^{1,2, * \mathbb{D}}$ \\ 1 Department of General Microbiology, Paulo de Goes Institute of Microbiology, \\ Federal University of Rio de Janeiro, Rio de Janeiro 21941912, Brazil; carenlsvilela@gmail.com (C.L.S.V.); \\ helena.villela@kaust.edu.sa (H.D.M.V.); caiorachid@micro.ufrj.br (C.T.C.d.C.R.); \\ flaviacarmo@micro.ufrj.br (F.L.d.C.); abvermelho@micro.ufrj.br (A.B.V.) \\ 2 Red Sea Research Center (RSRC), Division of Biological and Environmental Science and Engineering (BESE), \\ King Abdullah University of Science and Technology (KAUST), Thuwal 23955-6900, Saudi Arabia \\ * Correspondence: raquel.peixoto@kaust.edu.sa
}

\section{check for}

updates

Citation: Vilela, C.L.S.; Villela, H.D.M.; Rachid, C.T.C.d.C.; Carmo, F.L.d.; Vermelho, A.B.; Peixoto, R.S. Exploring the Diversity and Biotechnological Potential of Cultured and Uncultured Coral-Associated Bacteria. Microorganisms 2021, 9, 2235. https://doi.org/10.3390/ microorganisms 9112235

Academic Editor: Evgene Rosenberg

Received: 5 October 2021

Accepted: 24 October 2021

Published: 27 October 2021

Publisher's Note: MDPI stays neutral with regard to jurisdictional claims in published maps and institutional affiliations.

Copyright: (c) 2021 by the authors. Licensee MDPI, Basel, Switzerland. This article is an open access article distributed under the terms and conditions of the Creative Commons Attribution (CC BY) license (https:/ / creativecommons.org/licenses/by/ $4.0 /)$.
Abstract: Coral-associated microbes are crucial for the biology of their hosts, contributing to nutrient cycling, adaptation, mitigation of toxic compounds, and biological control of pathogens. Natural products from coral-associated micro-organisms (CAM) may possess unique traits. Despite this, the use of CAM for biotechnological purposes has not yet been adequately explored. Here, we investigated the production of commercially important enzymes by 37 strains of bacteria isolated from the coral species Mussismilia braziliensis, Millepora alcicornis, and Porites astreoides. In-vitro enzymatic assays showed that up to $56 \%$ of the isolates produced at least one of the seven enzymes screened (lipase, caseinase, keratinase, cellulase, chitinase, amylase, and gelatinase); one strain, identified as Bacillus amyloliquefaciens produced all these enzymes. Additionally, coral species-specific cultured and uncultured microbial communities were identified. The phylum Firmicutes predominated among the isolates, including the genera Exiguobacterium, Bacillus, and Halomonas, among others. Nextgeneration sequencing and bacteria culturing produced similar but also complementary data, with certain genera detected only by one or the other method. Our results demonstrate the importance of exploring different coral species as sources of specific micro-organisms of biotechnological and industrial interest, at the same time reinforcing the economic and ecological importance of coral reefs as reservoirs of such diversity.

Keywords: coral-associated micro-organisms (CAM); microbial diversity; biotechnology; enzymes; coral reefs; hydrolases

\section{Introduction}

Enzymes are biocatalyst agents with applications in different fields [1-4]. Hydrolases form a class of enzymes that perform biochemical catalysis using water to break chemical bonds and comprise most of the enzymes used in industry [5,6]. Among the hydrolases currently used in industrial processes, cellulases, chitinases, lipases, proteases, amylases, and esterases are often used in the transformation of substances with economic, environmental, and medical importance [6-8].

Micro-organisms are key sources of commercial enzymes, including hydrolases, to be obtained, characterized, and scaled up [1,9]. The use of natural products and microbial enzymes for biotechnological purposes has been extensively explored, especially in industrial and bioremediation processes [4,10-17]. Enzymes from micro-organisms account for $90 \%$ of the world market, with Europe and Asia as the main producers [18]. The economic value of the enzymes used in industrial applications was estimated between $\mathrm{U} \$ 5000$ and U\$5500 million [19].

Many enzyme-producing microbes come from marine ecosystems, which are therefore considered an important environment for prospecting for enzymes of commercial 
value [1,20-23]. For instance, microbial strains isolated from marine ecosystems have been reported producing several types of substances with protective properties against viruses, bacteria, fungi, and tumors, as well as enzymes of industrial interest [24-27]. Among marine ecosystems, coral reefs have been highlighted as a promising target for bioprospecting for natural products, due to the diversity of macro- and micro-organisms [28-31].

Corals are metaorganisms, or holobionts, which means that the host relies on an associated large and diverse microbial community [30,32-34]. These holobionts occupy niches that naturally select distinct microbial communities from the surrounding water [35-37]. Coral-associated micro-organism (CAM) assemblages are dynamic and vary according to several variables, including life stage, geographic location and environmental conditions as a means of adaptation/acclimation [38-42], constituting an endless source for prospecting for compounds with biotechnological potential $[43,44]$. As one of the most important variables selecting the CAM diversity and abundance is the species of coral host $[35,45,46]$, different coral species should be sources of specific (and possibly new) enzymes.

The use of culture-dependent techniques, associated or not with molecular diversity surveys, remains essential to isolate and test for microbial strains with a potential ability to produce specific bioactive compounds [31], in addition to their use as probiotics [47-53].

Although microbes isolated from corals have been reported to produce secondary metabolites that could be of technological interest [54-56], there is still very limited information about the biotechnological enzymatic potential of CAM [55,57-61]. Here, we screened the bacteria associated with three different coral species from the same region and evaluated how the isolated obtained might have different biotechnology potential. Investigation of new bioactive compounds is essential not only for industry, but also to increase even more the economic value of coral reefs, which can eventually contribute to enhance policies for their preservation and recovery [62].

\section{Materials and Methods}

A flowchart was designed to summarize the methodology used in this study. The activities are placed in the sequence in which they were performed (Figure 1).

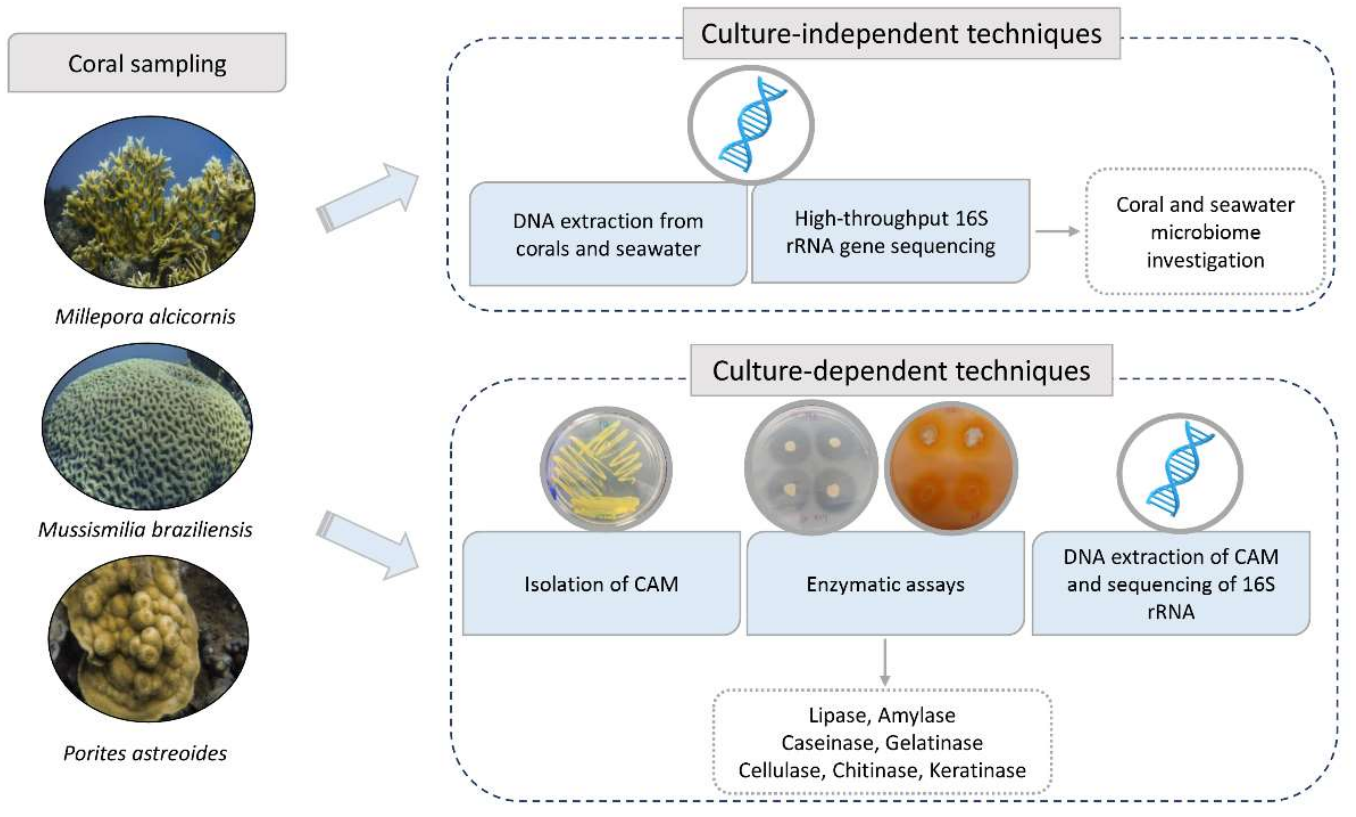

Figure 1. Flowchart summarizing the experimental activities. Coral and seawater samples had their DNA extracted for culture-independent analysis. Bacterial isolates were obtained from samples of the corals Millepora alcicornis, Mussismilia braziliensis, and Porites astreoides ( $\mathrm{Ma}, \mathrm{Mb}$ and $\mathrm{P}$ ) and screened for enzymes with industrial interest and identified by sequencing of rRNA 16S. (Coral photos credit: Augusto Machado). 


\subsection{Sample Collection}

Sampling permits were obtained from the Brazilian Institute of the Environment and Renewable Natural Resources (IBAMA)/Chico Mendes Institute for Biodiversity Conservation (ICMBio), permanent permit number 16,942, in accordance with the Instruction Normative No. 03/2014 of System Authorization and Information on Biodiversity (SISBIO), and from local authorities of the Municipality Environmental Agency (SMMA), Porto Seguro, Bahia, Brazil.

Samples of two Anthozoa (Scleractinia) species, Mussismilia braziliensis (Mb) and Porites astreoides $(\mathrm{P})$, and one Hydrozoa species, Millepora alcicornis $(\mathrm{Ma})$, were collected in the Municipal Park of Recife de Fora Reef, located in Porto Seguro, Brazil. The coral reef is known as 'Recife de Fora' and is located $3.2 \mathrm{~km}$ offshore near the city, between $16^{\circ} 23^{\prime} 30^{\prime \prime} \mathrm{S}$ and $16^{\circ} 25^{\prime} 06^{\prime \prime} \mathrm{S}$, and $38^{\circ} 58^{\prime} 30^{\prime \prime} \mathrm{W}$ and $38^{\circ} 59^{\prime} 18^{\prime \prime} \mathrm{W}$. The reef has an area of $17.5 \mathrm{~km}^{2}$ and the maximum water depth is $20 \mathrm{~m}$. Corals and seawater samples were collected at ambient temperature $\left(27^{\circ} \mathrm{C}\right)$. Annual temperature fluctuation ranged between $24^{\circ} \mathrm{C}(\mathrm{min})$ and $29^{\circ} \mathrm{C}$ (max), and the mean water temperature was $26.7^{\circ} \mathrm{C}( \pm 1.01)$ [63-65]. Fragments $(\sim 10 \mathrm{~g})$ for microbial surveys were collected in triplicate, in different colonies from each coral species, using a sterile hammer and chisel, and maintained at $4{ }^{\circ} \mathrm{C}$ until processing, while $10 \mathrm{~cm}^{2}$ fragments were used for species identification through skeleton observation and identification as described in Voolstra et al. [66]. The surrounding seawater was collected in triplicate and filtered with a Millipore membrane $(0.22 \mu \mathrm{m})$ to retain micro-organisms.

\subsection{DNA Extraction from Corals and Seawater}

DNA from the coral and water samples was extracted via the method of direct extraction with a PowerSoil ${ }^{\circledR}$ DNA Isolation Kit (MO BIO, Carlsbad, CA, USA) according to the manufacturer's protocol.

\subsection{Bacterial Composition by 165 rRNA Gene Sequencing}

About 10 ng of extracted genomic DNA from Millepora alcicornis, Mussismilia braziliensis, Porites astreoides, and seawater were used for the amplification of the V4 variable region of the 16S rRNA. A single-step 30-cycle PCR, using a HotStarTaq ${ }^{\circledR}$ Plus Master Mix Kit (Qiagen, Germantown, MD, USA) and the primers 515F/806R [67] as described in [34] was used. The overall bacterial diversity was assessed by hightrough-put sequencing using the platform Illumina MiSeq (Illumina, San Diego, CA, USA at the Argonne National Laboratory, http:/ /ngs.igsb.anl.gov (accessed on 2 March 2017), Lemont, IL, USA) with paired-end strategy, following the manufacturer's guidelines. The raw sequences were processed using Mothur v.1.39.1 software [68], as described in [69]. Briefly, Greengenes database (version from August 2013) was used with an 80\% confidence threshold, and sequences classified as Chloroplasts, Mitochondria, Archaea, Eukarya, or not assigned to any kingdom were removed. Operational taxonomic units (OTUs) were clustered using a $3 \%$ sequence dissimilarity cutoff, and all singletons were removed [70]. Samples were then randomly normalized to the same number of sequences (8890, with the exception of one replication of a P. astreoides sample that ended with 1048 sequences). The distribution of OTUs among samples was used to evaluate the bacterial community diversity and richness, as well to analyze the microbial structure analysis, which was performed using an NMDS ordination with Bray-Curtis distance, using PAST 3.20 software [71]. The analyses were conducted in triplicate for samples from seawater and $\mathrm{Mb}$, and in duplicate for $\mathrm{Ma}$ and $\mathrm{P}$, for which one replicate of each sample was excluded due to excess contamination by host mitochondrial rRNA. The data generated were deposited in the NCBI Sequence Read Archive (SRA) and are available under the Bioproject (PRJNA543129).

\subsection{Bacteria Isolation}

Each sample was macerated with a porcelain mortar and pestle, $48 \mathrm{~h}$ after collection. Five grams of the macerated samples were placed under $120 \mathrm{rpm}$ agitation at $25^{\circ} \mathrm{C}$ in Erlenmeyer flasks $(250 \mathrm{~mL})$ containing $5 \mathrm{~g}$ of sterile glass beads and $100 \mathrm{~mL}$ of sterile 
saline $(0.85 \% w / v \mathrm{NaCl})$. After $24 \mathrm{~h}$ of incubation, the contents of each macerated coral were placed in sterile Falcon tubes containing $50 \mathrm{~mL}$ of sterile saline $(0.85 \% \mathrm{w} / \mathrm{v} \mathrm{NaCl})$ and homogenized. After this step, dilutions $\left(10^{-1}\right.$ to $\left.10^{-6}\right)$ were performed in sterile Falcon tubes. A total of $0.1 \mathrm{~mL}$ of each dilution was inoculated in triplicate plates of LB culturemedium (Lisogeny Broth: $5 \mathrm{~g}$ yeast extract: $5 \mathrm{~g}$ sodium chloride: $10 \mathrm{~g}$ tryptone: $100 \mathrm{~mL}$ distilled water) [72] and MA culture-medium (Zobell Marine Agar) of different salinities $(1 \%, 3 \%, 6 \%$, and $10 \% \mathrm{NaCl})$. The plates were incubated at $25^{\circ} \mathrm{C}$ for $72 \mathrm{~h}$. Colonies with visually distinct morphologies were isolated and transferred to solid LB.

\subsection{Enzymatic Assays}

An enzymatic screening of the bacterial isolates was performed to evaluate the production of lipase, cellulase, amylase, gelatinase, caseinase, keratinase, and chitinase. Bacterial strains were inoculated in media containing specific substrates to stimulate the activity of each enzyme. To compare the amounts of enzymes produced, the hydrolysis index was evaluated [73-75]. The Hydrolysis Index (HI) was expressed as the relationship between the mean diameter of the degradation halo and the mean diameter of colony growth $[73,76]$. For all enzyme assays, the bacterial isolates were previously inoculated in a liquid LB medium for $48 \mathrm{~h}$ at $28^{\circ} \mathrm{C}$ under $120 \mathrm{rpm}$. Ten-microliter spots of microbial cultures were inoculated on each culture-medium plate for enzymatic assays. The enzymatic assay results were considered positive when halos around the colonies were detected, indicating consumption of the enzyme substrate. Halos and colony growth were measured using a caliper rule to calculate the hydrolysis index [77].

Spirit Blue Agar medium (SBA) (DIFCO Laboratories, Detroit, MI, USA) was used to evaluate the lipolytic activity, according to the manufacturer's protocol. Positive results were indicated by halo formation around the colony or yellowing of the SBA culturemedium, indicating hydrolysis of the substrate and production of fatty acids.

The activity of proteases against casein was evaluated using modified Bennett's agar (MBA) [77] with 1\% skim milk added as an enzyme substrate. An MBA medium was used to determine proteolytic activity against gelatin, with $0.4 \%$ gelatin $(w / v)$ added as an enzyme substrate. Readings were taken by adding $\mathrm{HgCl}_{2}$ solution $\left(15 \mathrm{~g} \mathrm{HgCl}_{2}, 20 \mathrm{~mL} \mathrm{HCl}\right.$, and distilled water to $100 \mathrm{~mL}$ ) [77].

The amylolytic activity of bacterial isolates was evaluated using the MBA medium with the addition of the starch enzyme substrate at a concentration of $1 \%(w / v)$. Readings were taken by adding lugol (iodine solution) [77].

The ability of micro-organisms to hydrolyze cellulose was tested on agar plates containing carboxymethylcellulose (CMC agar). The plates were evaluated using $0.1 \%$ Congo red solution $(w / v)$ [78].

Chitinase production by the bacterial isolates was evaluated using colloidal chitin as a substrate in the culture-medium containing the following reagents: $0.7 \mathrm{~g} \mathrm{~K}_{2} \mathrm{HPO}_{4}, 0.3 \mathrm{~g}$ $\mathrm{KH}_{2} \mathrm{PO}, 0.5 \mathrm{~g} \mathrm{MgSO}_{4} .5 \mathrm{H}_{2} \mathrm{O}, 0.01 \mathrm{~g} \mathrm{FeSO}_{4} .7 \mathrm{H}_{2} \mathrm{O}, 0.001 \mathrm{~g} \mathrm{ZnSO}_{4}, 0.001 \mathrm{~g} \mathrm{MnCl}$, and $20 \mathrm{~g}$ of agar in $1000 \mathrm{~mL}$ of distilled water [79].

The isolates were inoculated in $5 \mathrm{~mL}$ test tubes containing a Feather medium $(11.876 \mathrm{~g}$ $\mathrm{Na}_{2} \mathrm{HPO}_{4}, 9.072 \mathrm{~g} \mathrm{KH}_{2} \mathrm{HPO}_{4}, 1000 \mathrm{~mL}$ distilled water, and 1\% chicken feathers as a substrate, $\mathrm{pH}$ 7.2) [80]. Feathers were provided by a poultry processing company. These feathers were washed with detergent, delipidated in chloroform:methanol $(1: 1 \mathrm{v} / \mathrm{v})$, and dried at $60{ }^{\circ} \mathrm{C}$ before use. White contour feathers were used for the standardization of all tests.

For the enzymatic screening and inoculation in the Feather medium, the isolates were previously grown in LB broth and were washed twice with sterile saline at $0.85 \%$. The inoculum (30-300 UFC) was added to the Feather medium, and the test tubes were incubated under agitation at $150 \mathrm{rpm}$ for 3 days at $28^{\circ} \mathrm{C}$. 


\subsection{DNA Extraction from Isolates}

The DNA of all microbial isolates of visually distinct morphotypes was extracted via enzymatic lysis, using the commercial Wizard ${ }^{\circledR}$ Genomic DNA extraction kit (Promega, Madison, WI, USA), following the manufacturer's protocol. The extracted DNA was evaluated for integrity and quality by electrophoresis in $0.8 \%$ agarose gel in $0.5 \times \mathrm{TBE}$ buffer (45 mM Tris-borate, 1 mM EDTA, pH 8.0).

\subsection{Identification of Isolates}

The identification of the isolates was obtained through $16 \mathrm{~S}$ rRNA gene sequencing, using the PCR product obtained with the primers $27 \mathrm{f}$ (5'-AGAGTTTGATCATGGCTCAG$\left.3^{\prime}\right)$ and 1492r (5'-GTTTACCTTGTTACGACTT-3') [81]. The reaction mixtures contained $50 \mathrm{~mL}$ of buffer $1 \times$ Taq polymerase, $2.5 \mathrm{mM} \mathrm{MgCl} 2,200 \mu \mathrm{mol}$ of each dNTP, $20 \mu \mathrm{mol}$ of each primer, 2.5 U Taq polymerase (Fermentas, Burlington, ON, Canada), and sterile Milli$\mathrm{Q}$ water, amplified using a PCR program of DNA denaturation $\left(3 \mathrm{~min}\right.$ at $\left.94{ }^{\circ} \mathrm{C}\right)$, followed by 35 cycles of $40 \mathrm{~s}$ at $94^{\circ} \mathrm{C}, 1 \mathrm{~min}$ at $55^{\circ} \mathrm{C}$, and $2 \mathrm{~min}$ at $72{ }^{\circ} \mathrm{C}$, and extension at $72{ }^{\circ} \mathrm{C}$ for $10 \mathrm{~min}$. The amplified genes were purified on $1.6 \%$ agarose gel with the Illustra ${ }^{\mathrm{TM}} \mathrm{GFX}^{\mathrm{TM}}$ PCR DNA and Gel Band Purification Kit (GE Healthcare Biosciences, Buckinghamshire, UK).

Sequencing reactions were performed on an automated $\mathrm{ABI}$ 3130-XL sequencer, using the end primers $27 \mathrm{f}\left(5^{\prime}\right.$-AGAGTTTGATCATGGCTCAG-3') and 1492r (5'-GTTTACCTTGT TACGACTT- $\left.3^{\prime}\right)$, and two primers for intermediate regions at positions $532 \mathrm{f}\left(5^{\prime}\right.$-CGTGCCAG CAGCCGCGGTAA-3') and 907r (5'-CCGTTAATTCMTTTGAGTTT-3') [81] for complete sequencing of the $16 \mathrm{~S}$ rRNA gene. The sequences obtained in this study were uploaded and are available at GenBank under accession numbers KM877218-KM877266.

The sequences were processed by the quality control tool Sanger Pipeline (Ribosomal Database Project, RDP) to remove the low-quality sequences. Then, the four reads from sequencing were assembled in contigs using Bioedit software [82]. To determine the nearest neighbors and to assemble the phylogenetic tree, sequences from similar organisms were obtained from the pipeline SeqMatch (RDP) [83]. All sequences obtained were aligned using ClustalW, available in the Bioedit software [84]. A phylogenetic tree was constructed and edited using MEGA X $[85,86]$ with the Maximum Likelihood method, using the replacement model Tamuna-Nei Model [87] and a bootstrap value of 500 .

\section{Results}

\subsection{Alpha-Diversity and Microbiome Survey Provided by Molecular Tools}

After sample processing and the removal of the short and low-quality sequences, 8890 reads were obtained from seawater and coral samples (with exception of one missed replicate from $\mathrm{P}$ ). The rarefaction curve indicated that most of the bacterial community was covered by the sequencing technique (Figure S1). According to the mean values obtained, the Chao1 richness indexes for $\mathrm{Mb}$ and $\mathrm{P}$ were 436 and 396, respectively, while the index in seawater was 361 and in Ma was 108. The mean Shannon diversity index for the samples from $\mathrm{Mb}$ was 4.59 and for $\mathrm{P}$ was 3.99, demonstrating higher bacterial diversity, whereas the samples from Ma had a mean value of 2.48. The Shannon index in the seawater sample was 3.31, indicating high bacterial diversity (Supplementary Table S1).

Overall, the bacterial community of seawater was significantly different from those associated with corals (PERMANOVA, $p<0.01$ ) (Figure 2). Although a paired t-test was not possible due to the loss of one replicate from $\mathrm{Ma}$ and $\mathrm{P}$, the samples from $\mathrm{Mb}$ and $\mathrm{P}$ seemed to be more closely related compared to Ma or seawater. 


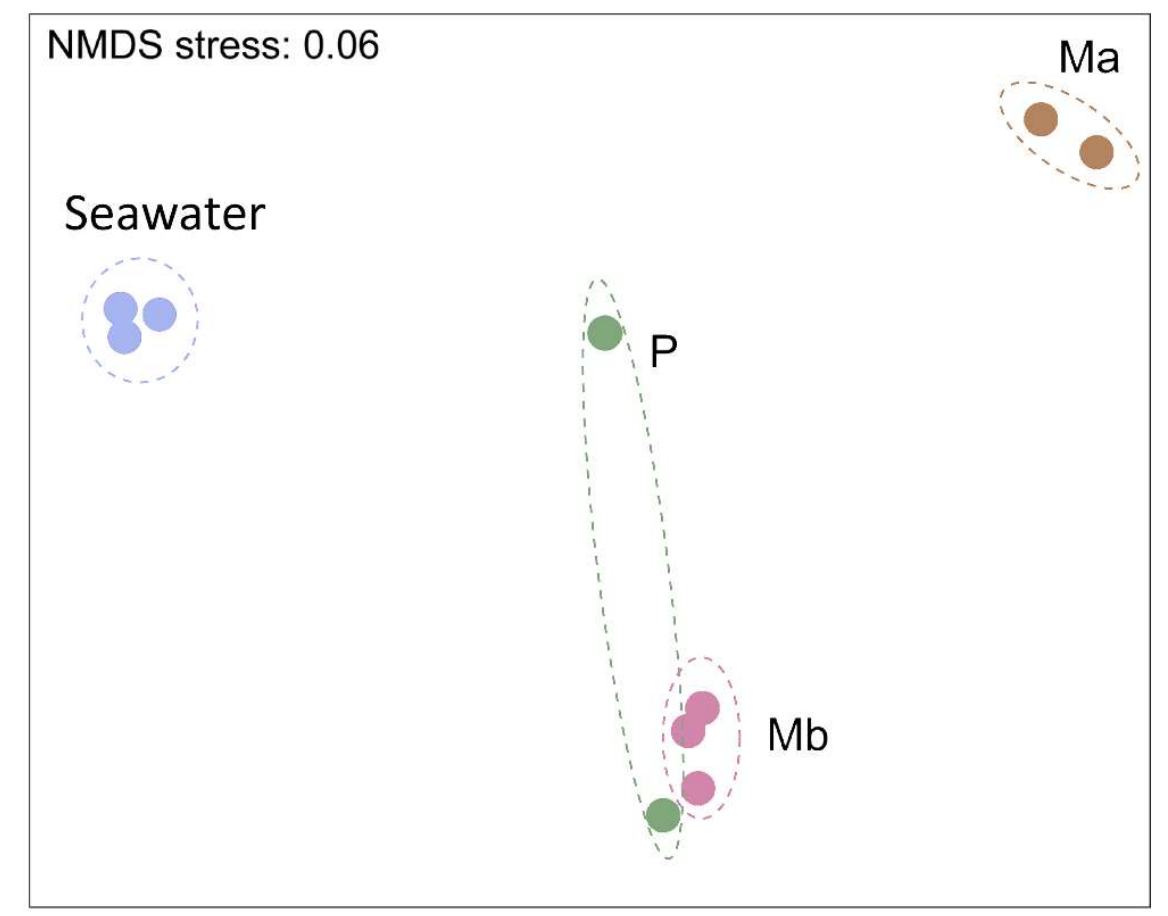

Figure 2. Non-metric multidimensional scaling ordination (NMDS) of Millepora alcicornis (Ma), Mussismilia braziliensis $(\mathrm{Mb})$, Porites astreoides $(\mathrm{P})$, and seawater samples based on Bray-Curtis similarity distances.

Taxonomic analysis demonstrated that at the phylum level, Proteobacteria was the most abundant in $\mathrm{P}$ and $\mathrm{Mb}$. The Ma was dominated by Firmicutes, whereas Proteobacteria was the second-largest group (Figure S2). The phylum Cyanobacteria had the highest relative abundance in the seawater samples, and Synechococcophycideae was the dominant microbial class in seawater (Figure S2).

Some genera were specifically found to be associated with each coral species (Figure 3a,b), such as Thalassospira sp. plus another 7 specific genera in Ma (Figure 3a). Similarly, 21 genera appeared to be specifically associated with $\mathrm{P}$, whereas 35 genera were exclusively associated with $\mathrm{Mb}$, such as Prochlorococcus and Fusobacteriaceae $u 114$ (Figure 3c). Twenty-one genera were shared among the three coral species, including Synechococcus, Acinetobacter, Mycobacterium, Staphylococcus, Pseudomonas, and Bacillus (Figure 3a). A total of 8 genera were shared between $\mathrm{Ma}$ and $\mathrm{Mb}$, and Arcobacter was found in $\mathrm{Ma}$ and $\mathrm{P}$, but not in $\mathrm{Mb}$. A large number of genera were shared between $\mathrm{Mb}$ and $\mathrm{P}$ (23 genera), but were not present in Ma. Synechococcus was the most predominant genus in seawater, while Mycobacterium predominated in Ma (Figure 3c). Samples from Mb and P showed a higher diversity of associated genera, with Acinetobacter the most abundant in $\mathrm{Mb}$ and Pseudomonas and Staphylococcus in P (Figure 3c).

\subsection{Isolation and Identification of CAM}

A total of 37 bacterial isolates exhibiting different morphotypes were obtained from the three coral species. Among the visually different morphotypes, 13 were isolated from $\mathrm{Ma}, 13$ from $\mathrm{Mb}$, and 11 from $\mathrm{P}$ (Figures $3 \mathrm{~d}$ and 4).

The isolates obtained in this study were distributed among a diverse group of known genera, such as Bacillus sp., Exiguobacterium sp., Psychrobacter sp., Arthrobacter sp., Acinetobacter sp., Raoultella sp., Virgibacillus sp., Cellulomonas sp., Micrococcus sp., and Staphylococcus sp. (Figure 3d). 
a Culture-independent approach
(molecular tools)

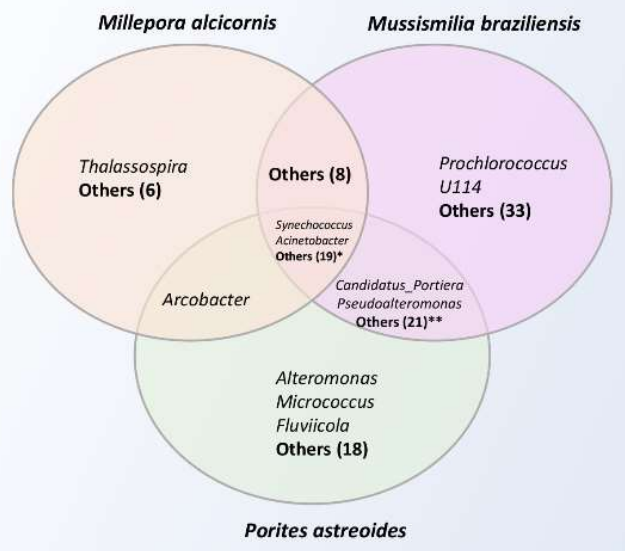

C $30 \%$

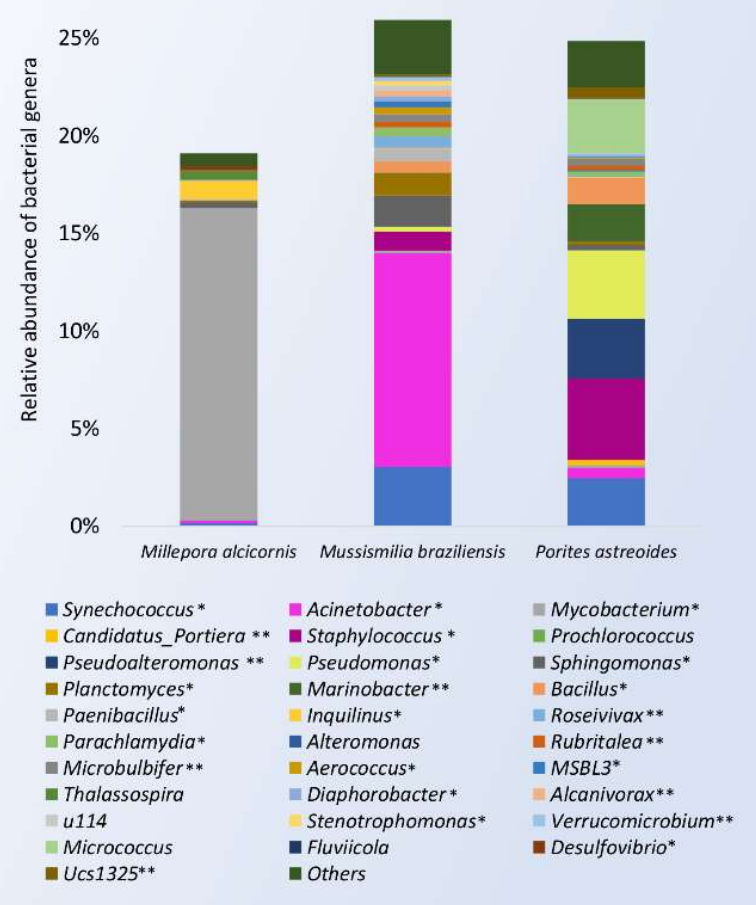

b Culture-dependent approach (traditional cultivation tools)

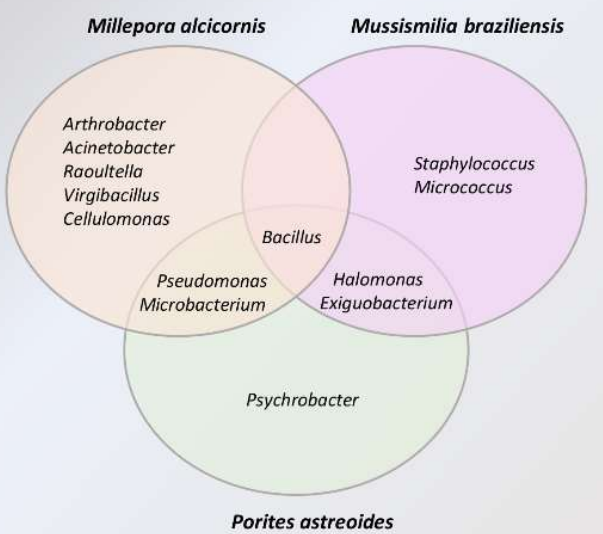

d

14
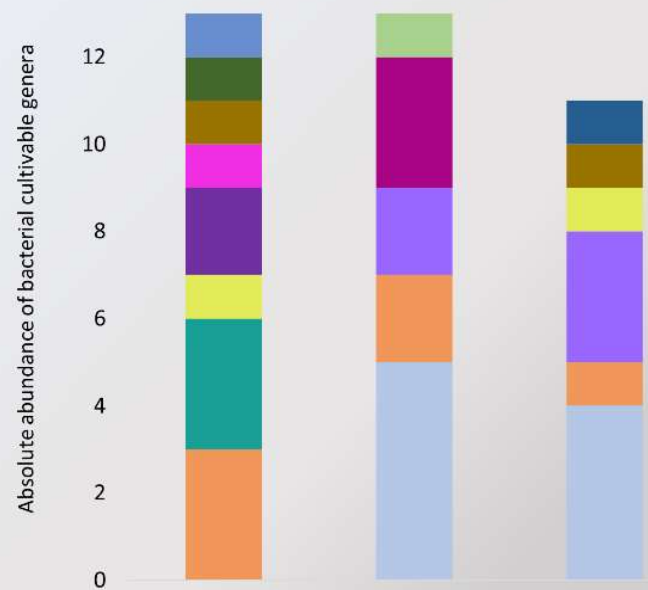

Millepora alcicornis Mussismilia braziliensis Porites astreoides

Exiguobacterium Bacillus

Staphylococcus Arthrobacter Halomonas

Pseudomonas Raoultella Acinetobacter

Mseudomonas Acinetobacter

Virgibacillus

Figure 3. (a) Venn diagram showing the bacterial genera obtained from culture-independent methods. (b) Venn diagram showing the bacterial genera obtained from culture-dependent methods. (c) Taxonomic classification and relative abundance of the bacterial genera from $\mathrm{Ma}, \mathrm{Mb}$, and $\mathrm{P}$ by molecular methods. (d) Absolute abundance of genera from $\mathrm{Ma}, \mathrm{Mb}$, and $\mathrm{P}$ by culture-dependent methods. * indicates the microbial genera shared by all coral samples in the list below the respective column; ${ }^{* *}$ indicates the microbial genera shared by $\mathrm{Mb}$ and $\mathrm{P}$ in the list below the respective column in $(\mathbf{a}, \mathbf{c})$. 


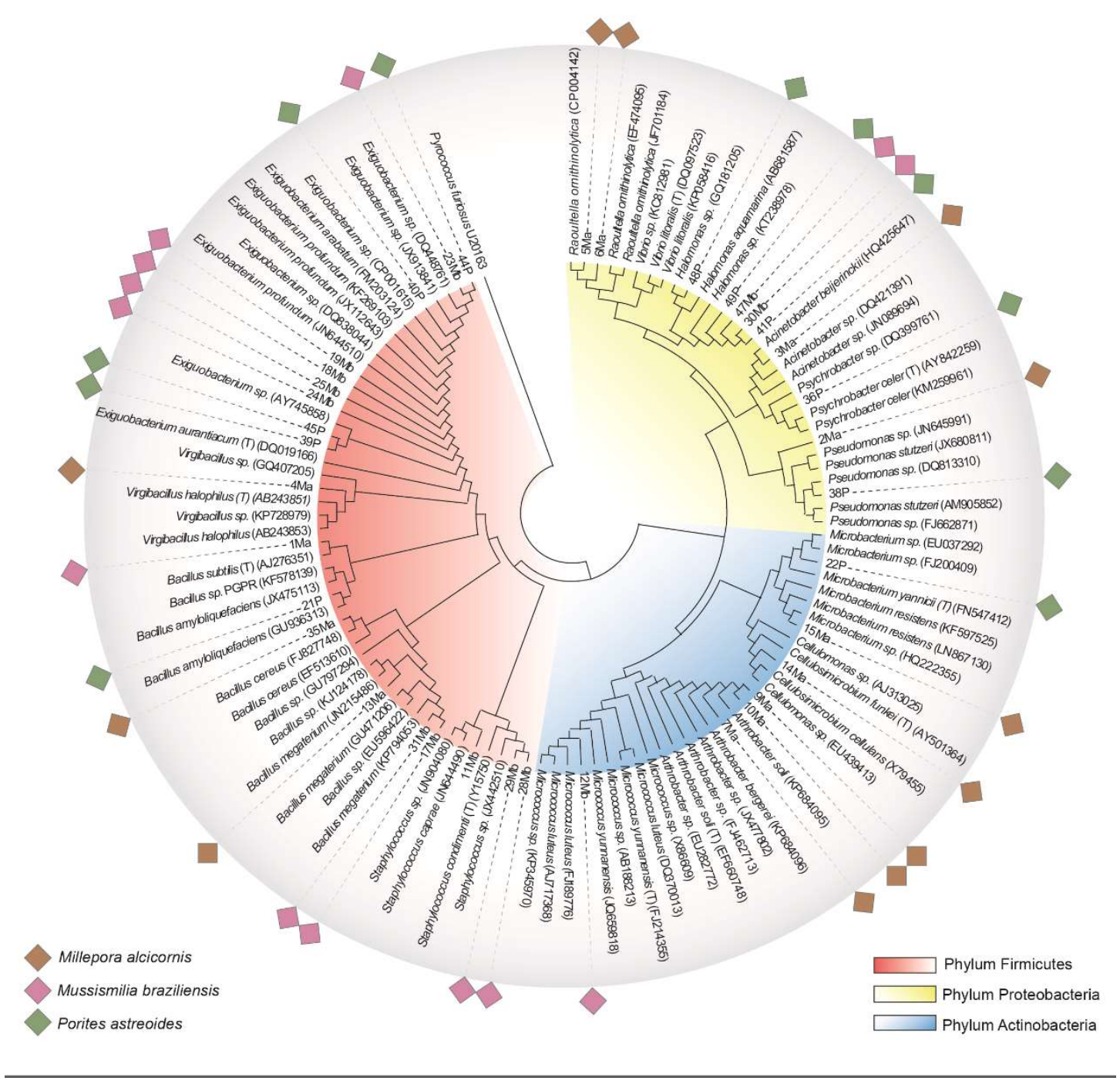

Figure 4. Phylogenetic tree based on the sequences of the $r r s$ ( $>600 \mathrm{bp}$ ) gene, indicating the relationships between 37 isolates and their closest species. The tree was constructed using the MEGA X program based on the Maximum Likelihood method and Tamura-Nei model. Bootstrap analysis with 500 replicates was performed, and the results are shown at branch points. The GenBank accession number of each species is indicated in parentheses. Each color label indicates the coral source of the isolates (brown, M. alcicornis; pink, M. braziliensis; and green, P. astreoides). Each branch color indicates the phylum of the isolates (red, Firmicutes; blue, Actinobacteria; and yellow, Proteobacteria).

\subsection{Enzymatic Potential of the Bacterial Strains}

The results obtained from the enzymatic assays are summarized in Figure 5C. Of the obtained isolates, 21 produced lipase, 16 caseinase, 16 keratinase, 6 amylase, 4 gelatinase, 5 chitinase, and 5 cellulase. The isolates showing positive results and the hydrolysis index of the different enzymes evaluated were different for each coral species (Figures 5C and S2).

The coral species explored in this study have distinct morphologies (Figure 5A). We can see that all coral species harbored micro-organisms able to produce enzymes. The phylogenetic relationship between the isolated $\mathrm{CAB}$ demonstrated that the enzymatic production was not related specifically to the bacterial morphotypes obtained or the coral species (Figure 5B). The Ma was the source of a higher number of morphotypes (40\%) with the ability to produce enzymes. However, the morphotypes with the highest $\mathrm{HI}$ for the enzymes tested were obtained from P (Figure 5C). 


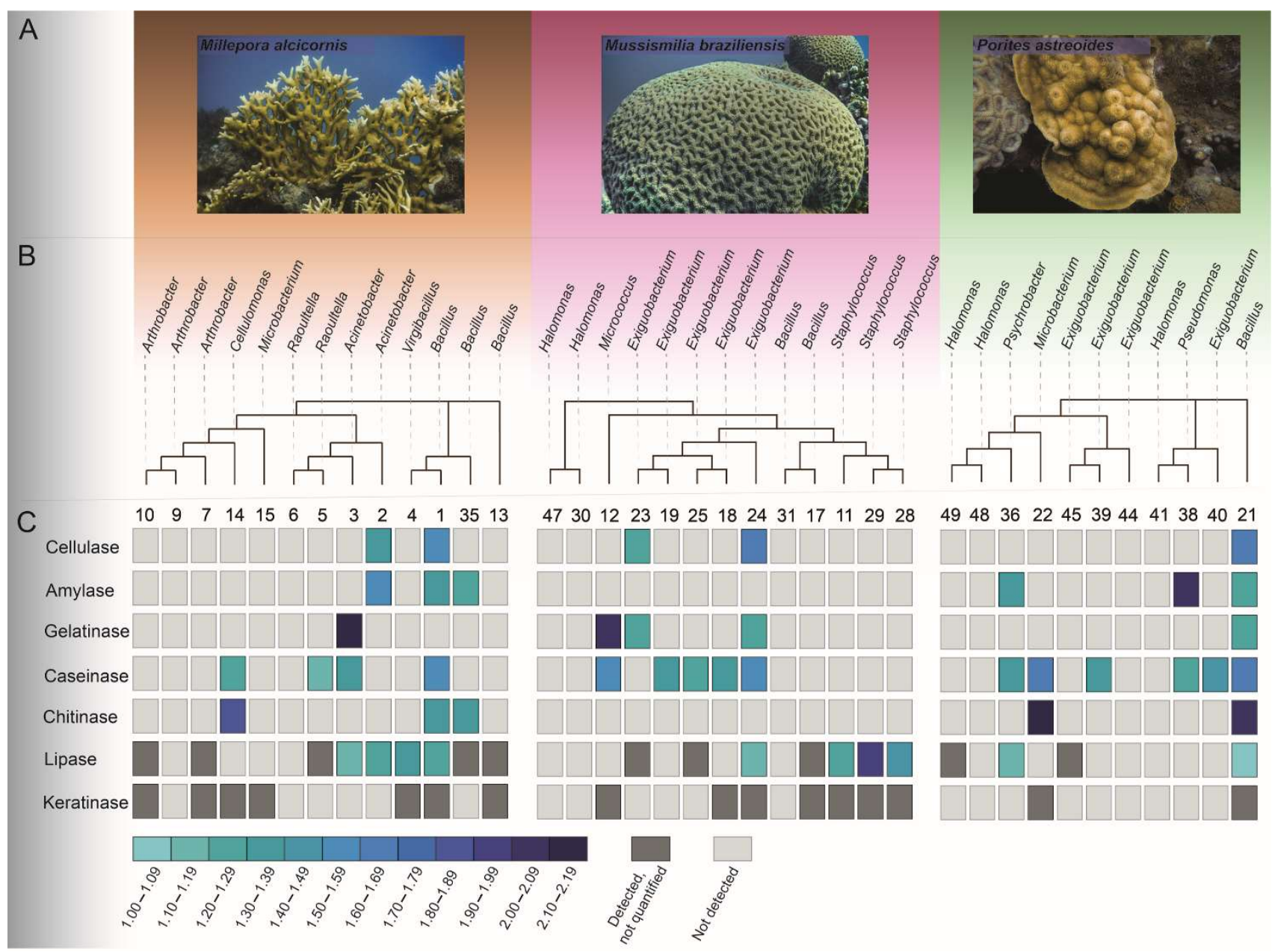

Figure 5. (A) In-vivo photographs of the Ma, Mb, and P corals (Credits: Augusto Machado); (B) Phylogenetic relationship and taxonomic identification of isolates from each coral sample; (C) Graphical representation of enzyme production, with hydrolysis indexes of bacterial isolates from corals. The color gradient indicates the hydrolysis index of the enzyme substrate.

Most of the lipase-positive morphotypes were members of Firmicutes (Figure 6a). Although the majority of the lipase-positive morphotypes were obtained from Ma $(n=9)$, isolate $29-\mathrm{Mb}$, obtained from $\mathrm{Mb}$, and identified as Staphylococcus sp., they showed the highest hydrolysis index for this enzyme (1.91). In addition, a large number of caseinase producers $(\mathrm{n}=16)$ were also obtained, also dominated by representatives of Firmicutes (Figure 6b). Morphotypes 21-P (Bacillus amyloliquefaciens) and 22-P (Microbacterium sp.), both isolated from $\mathrm{P}$, showed the highest hydrolysis indexes. Amylase production, however, was not detected in isolates obtained from $\mathrm{Mb}$, being found in Proteobacteria and Firmicutes morphotypes obtained from Ma and P at similar abundances (Figure 6e). The highest HI was found for morphotype 38-P, identified as Pseudomonas stutzeri (Table S2).

Similarly, isolates obtained from $\mathrm{Mb}$ did not show chitinase activity, while three (1-Ma, 14-Ma, and 35-Ma) and two (21-P and 22-P) isolates from Ma and $\mathrm{P}$, respectively, showed this capacity (Figure 5C). These isolates were identified as Bacillus sp., Cellulomonas sp., Bacillus cereus, Bacillus amyloliquefaciens, and Microbacterium sp., respectively. The mean hydrolysis index of the morphotypes obtained from $\mathrm{P}$ was higher (2.07) than the mean index of those obtained from Ma (1.53) (Table S2). No Proteobacteria representatives were able to produce chitinase (Figure $6 \mathrm{~d}$ ). 


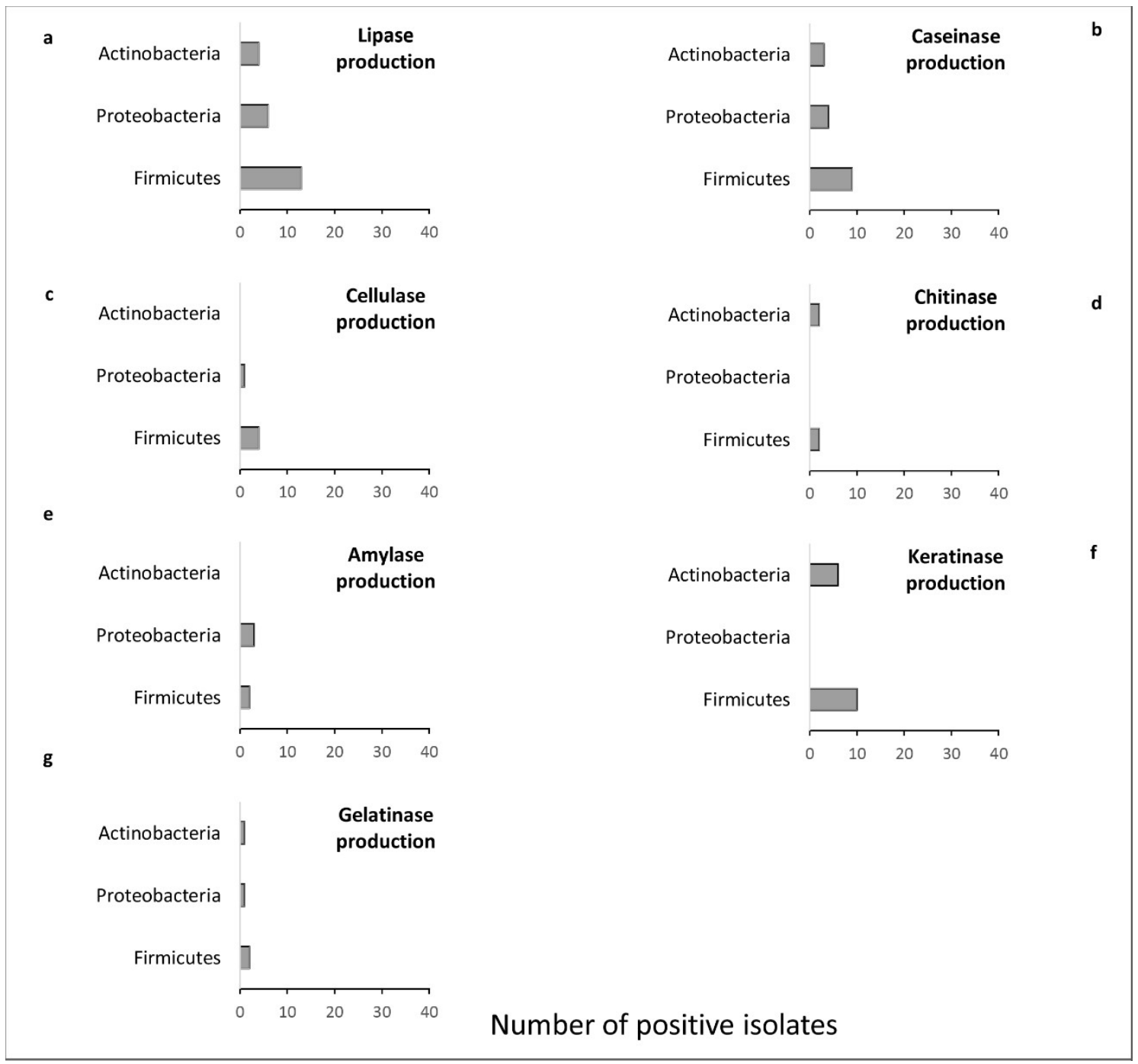

Figure 6. Summary of enzymatic activities found in each bacterial phylum. (a) lipase production; (b) caseinase; (c) amylase; (d) chitinase; (e) cellulase; (f) gelatinase; (g) keratinase.

Regarding cellulase production, the hydrolysis indexes were similar across morphotypes isolated from the different coral species, and were dominated by Firmicutes representatives (Figure 6e), whereas morphotypes obtained from Ma showed the highest hydrolysis indexes for gelatinase production. Isolate 3-Ma (Acinetobacter beijerinckii) showed the highest gelatinase hydrolysis index (2.11), while the lowest index was obtained from isolate 24-Mb (Exiguobacterium profundum) (1.23) (Table S2). The ability to produce gelatinase was found in all phyla isolated in this study (Figure 6f). Keratinolytic activity was more frequent in Firmicutes $(n=10)$ and was also found in 6 Actinobacteria isolates. This activity was not found in members of the phylum Proteobacteria (Figure 6g).

\section{Discussion}

Culture-independent methods are crucial to investigate host-associated microbial communities and can also drive bioprospecting surveys that use culture-dependent methods [88], which are extremely valuable to explore the physiological and biotechnological potential of micro-organisms $[44,50,89]$. Here, culture-dependent and independent approaches were combined to build and explore a CAM collection that can be further applied in industrial or remediation activities, due to their enzymatic production potential. The collection of bacteria obtained from the three coral species studied demonstrated the 
ability to produce a variety of target enzymes, indicating that coral is a good source for biotechnological prospecting.

The grouping pattern found with the use of molecular tools clearly indicated that the coral samples hosted a significantly different microbial community (and therefore a source of CAM) compared to the seawater. This difference was also apparent when comparing the three coral species, as previously observed $[90,91]$.

Enzyme production by CAM can be either negative or positive for the host. Proteases, for example, have been reported as playing roles in pathogenic response, promoting coral tissue necrosis, and contributing to the progression of diseases [92]. Gelatinase production has also been correlated with pathogenic activity, such as in coral bleaching promoted by Vibrio shiloi [93]. Conversely, the same enzymatic metabolisms can also be crucial for the host's homeostasis and defense, as exemplified by the proteolytic activity of bacterial isolates associated with coral protection against disease [94].

A complex and diverse bacterial community able to produce the enzymes tested was identified. Although the culture-dependent approach was not designed for ecological comparisons, but rather for overall recovery of the visually distinct morphotypes, the isolates obtained from Ma were mainly identified as Firmicutes, while isolates obtained from other coral species were more evenly distributed. The overall enzymatic survey detected 21 lipase-positive morphotypes. Among these, 5 belonged to the genus Bacillus; morphotype 21-P showed the highest HI (1.07) in this genus. Several studies have reported lipase production by Bacillus recovered from other sources [95-100]. We also detected the presence of other lipase producers from other genera, such as Pseudomonas, Acinetobacter, Virgibacillus, Raoultella, Staphylococcus, Arthrobacter, Micrococcus, Exiguobacterium, Psychrobacter, and Halomonas. All these genera have been previously described as lipase producers [100-106], but with representatives isolated from other organisms or environmental samples. Additionally, morphotype 4-Ma, identified as Virgibacillus halophilus (99\%), was also obtained and showed a lipase production $\mathrm{HI}$ of 1.38. This is the first report of lipase production by this microbial species, and the potential and peculiarities of this (potentially new) enzyme should be investigated in further experiments.

Lipases are enzymes used for lipid hydrolysis, with a broad potential for industrial application [107,108]. Microbial lipases have been used extensively in food production and processing; preparation of detergents, pharmaceuticals, and cosmetics; and cleaning processes such as treatment of sewage and some types of industrial waste $[109,110]$. Marine micro-organisms have been reported as lipase producers [110-113]. Similarly, proteases are used widely in industry, such as pharmaceutical, leather, wastewater, brewing, food, and others $[114,115]$. This group comprises $60 \%$ of the global market for enzymes, and microbial proteases have an advantage over those of animal and plant origin, due to their low cost [116]. Proteases discovered from marine sources may show resistance to temperature [117], alkaline properties [118], and other characteristics with industrial interest [119].

Members of the genera Micrococcus, Acinetobacter, Bacillus, and Exiguobacterium able to produce gelatinase were also obtained. Most of the morphotypes capable of producing gelatinase were obtained from $\mathrm{Mb}$ although the most efficient was 3-Ma (Acinetobacter beijerinckii) from $\mathrm{Ma}(\mathrm{HI}=2.11)$. Gelatinase is a metalloprotease that acts specifically on gelatin substrates $[120,121]$, used in chemical, medical, pharmaceutical, cosmetics, food, and other industries [122,123], and that has previously been isolated from marine invertebrates [124-126], and is frequently related to diseased corals [127,128]. One of the applications of gelatinase is based on its capacity to degrade tissue associated with tumor metastasis [129-131] and promote epithelial regeneration [132,133]. Thus, prospecting for more efficient and novel types of gelatinases with different properties could represent an important step in the medical field and other biotechnological processes.

Sixteen percent of the bacterial isolates obtained here were amylase-positive, identified as members of the genera Bacillus, Psychrobacter, and Pseudomonas isolated from P and $\mathrm{Ma}$, but not from $\mathrm{Mb}$. No Actinobacteria isolate obtained was able to produce amylase. 
Morphotype 38-P (Pseudomonas stutzeri), the best amylase producer (Figure 5B,C), which agrees with previous data indicating the high potential of Pseudomonas sp. isolates to produce a variety of amylase types [134-137]. Curiously, though, we detected starch hydrolysis performed by Psychrobacter celer (isolate 36-P), for the first time, and this isolate was also capable of hydrolyzing lipids and casein.

Bacterial isolates from the corals Acropora sp. and Montipora sp., collected in Indonesia, that showed activity against Black Band Disease (BBD) were also able to hydrolyze starch and casein [94]. We obtained a total of 16 isolates that were also able to produce caseinase, which has the most important enzymatic activity associated with CAM obtained from P. In coral samples, previously reported caseinase producers were members of the genera Vibrio and Pseudoalteromonas, the latter described as containing beneficial micro-organisms for coral (BMC) traits $[94,138]$.

Chitinase producers have already been reported in corals playing a role against stresses generated by pathogens [139]. Chitinase is currently applied in the industry for biological control of fungi and insects. Additionally, the production of drugs and oligomers generated by the enzymatic hydrolysis of chitosan and chitin, is of high economic importance due to medical, industrial, and agricultural applications [140-143]. Positive chitinase CAM belonging to the genera Bacillus, Cellulomonas, and Microbacterium was obtained from $\mathrm{Ma}$ and $\mathrm{P}$, but not from Mb. A study by Yoshioka, et al. (2017) [144] observed the expression of chitinase-like and cellulase genes during different coral life stages and detected these two enzymes in coral tissue extracts. These observations suggest that chitinase and cellulase are important for coral health, which highlights their potential as good sources for prospecting for these two enzymes. Coincidently or not, cellulase-producing CAM was isolated from all three coral species, and identified as Bacillus, Pseudomonas, and Exiguobacterium.

Among the cultured-CAM reported here, $43 \%$ were able to produce keratinase from all coral sources tested. This enzymatic group stands out of the other proteases due their capacity to hydrolyze insoluble proteins with disulfide bonds in their structure $[145,146]$. Keratinases are often applied in food, textiles, leather, medicine, pharmaceutical, cosmetics and agricultural industries, and poultry processing $[147,148]$. We obtained keratinase producers belonging to a diversity of genera (i.e., Staphylococcus, Arthrobacter, Microbacterium, Exiguobacterium, Virgibacillus, Micrococcus, and Cellulomonas) but mainly represented by Bacillus sp., well-known keratinase producers [149-151]. The production of keratinase has been correlated to biofilm inhibition of the pathogenic bacterial strains Staphylococcus aureus and Escherichia coli [152], which may be translated to corals as a potential mechanism for their protection against bacterial infections.

Overall, our results demonstrate that all three coral species explored (i.e., M. braziliensis, M. alcicornis, and P. astreoides), exhibit a diversity of specific CAM of biotechnological interest. Each species provided specific results that can be more or less significant for the screening of each enzyme. For instance, morphotype 21-P (Bacillus amyloliquefaciens) obtained from $P$ was able to produce all the 7 target enzymes. Further, enzymatic assays indicated that bacterial isolates from Ma produced the widest diversity of types of enzymes, in general, except for caseinase and gelatinase. The best caseinase producers were obtained from $\mathrm{P}$, which showed the highest $\mathrm{HI}$ for this enzyme. These data indicate that coral diversity collectively harbors distinct CAM with a range of enzymatic activity.

The use of culture-dependent and independent methods showed that these approaches provided complementary results regarding the presence and enzymatic activity of specific CAM. Interestingly, the genera Arthrobacter, Acinetobacter, Raoutella, Virgibacillus, and Cellulomonas were detected in Ma only through culture-dependent methods, while the most abundant genus detected by molecular tools, Mycobacterium, was not isolated from Ma samples, likely due to culture media and strategy limitations [31]. In addition, Exiguobacterium sp. is another example of a genus obtained from culture-dependent methods that could not be identified through the use of the molecular survey in $\mathrm{Mb}$. On the other hand, Pseudomonas sp. and Bacillus sp. were recovered by both culture-dependent and independent methods, again likely due to the applied cultivation strategy. 
Overall, these results feature the importance of polyphasic approaches in ecological and biotechnological studies. Moreover, it indicates the need for advanced techniques to cultivate micro-organisms, such as in situ, high-throughput, iChip, membrane-based diffusion, and other approaches $[43,153]$. These methods can enable recovery of a greater diversity and abundance of microbial isolates, which can be related to production of natural products with industrial and ecological interest [154-157].

\section{Conclusions}

Our results indicated that different coral species collected at the same geographic site under the same conditions contained distinct (cultured and uncultured) associated bacterial members, and that each coral holobiont may be a unique source of enzymes with biotechnological potential.

Among the three coral species studied, Millepora alcicornis harbored the highest diversity of morphotypes and the most isolates capable of producing the enzymes investigated, considering the culture strategy used. Some of the isolates showed promising potential for multiple biotechnological applications, such as the 21-P morphotype, identified as Bacillus amyloliquefaciens, which showed positive results for the production of all seven enzymes screened. Representatives of bacterial genera not previously associated with the production of specific enzymes were also obtained from corals, such as the production of lipase by Virgibacillus halophilus and amylase by Psychrobacter celer. In addition, our data highlights that the utilization of a polyphasic approach provides complementary data for the investigation of CAM diversity and biotechnological potential.

Supplementary Materials: The following are available online at https:/ / www.mdpi.com/article/10 .3390/microorganisms9112235/s1; Figure S1: Rarefaction curves of 16S rRNA sequences obtained by Illumina sequencing from seawater, Millepora alcicornis (Ma), Mussismilia braziliensis (Mb) and Porites astreoides (P). Each colored line represents the OTUs of the samples.; Figure S2: (a) Taxonomic classification and relative abundance of the bacterial phyla from seawater, Millepora alcicornis, Mussismilia braziliensis, and Porites astreoides. (b) Taxonomic classification and relative abundance of the bacterial classes from seawater, Millepora alcicornis, Mussismilia braziliensis, and Porites astreoides. The classifications were based on the Greengenes database, employing an $80 \%$ confidence threshold. Table S1: $\alpha$-diversity indexes of the samples from seawater $(\mathrm{n}=3)$ and corals Millepora alcicornis $(\mathrm{n}=2)$, Mussismilia braziliensis $(\mathrm{n}=3)$ and Porites astreoides $(\mathrm{n}=3)$. Table S2: Hydrolysis index of enzyme production for lipase, keratinase, caseinase, amylase, chitinase, cellulase and gelatinase by microorganisms isolated from the corals Millepora alcicornis (Ma), Mussismilia braziliensis (Mb) and Porites astreoides (P).

Author Contributions: Conceptualization, C.L.S.V., R.S.P.; methodology, C.L.S.V., C.T.C.d.C.R., F.L.d.C., A.B.V.; formal analysis, C.L.S.V., C.T.C.d.C.R.; writing-original draft preparation, C.L.S.V., H.D.M.V., F.L.d.C., R.S.P. writing-review and editing, C.L.S.V., C.T.C.d.C.R., H.D.M.V., R.S.P. All authors have read and agreed to the published version of the manuscript.

Funding: This study was supported by the Conselho Nacional de Desenvolvimento Científico e Tecnológico (CNPq) and King Abdullah University of Science and Technology CCF grant BAS/1/109501-01.

Data Availability Statement: The results of the sequencing of the bacterial composition can be found in the NCBI site, under the Bioproject (PRJNA543129). Link: https://www.ncbi.nlm.nih. gov / search/all/?term=PRJNA543129 (accessed on 5 October 2021). The sequences of the bacterial isolates obtained in this study were uploaded and are available at GenBank under the accession numbers KM877218-KM877266. Link: https://www.ncbi.nlm.nih.gov/genbank/ (accessed on 5 October 2021).

Acknowledgments: The authors would like to thank the Coral Vivo Project and its sponsors (Petrobras and Arraial d'Ajuda Eco Parque) for their support in sampling these corals, and to Cristiano M. Pereira for collecting the coral samples.

Conflicts of Interest: The authors declare no conflict of interest. 


\section{References}

1. Parte, S.; Sirisha, V.L.; D'Souza, J.S. Biotechnological applications of marine enzymes from algae, bacteria, fungi, and sponges. In Advances in Food and Nutrition Research; Academic Press: Cambridge, MA, USA, 2017; pp. 75-106.

2. Chapman, J.; Ismail, A.E.; Dinu, C.Z. Industrial applications of enzymes: Recent advances, techniques, and outlooks. Catalysts 2018, 8, 238. [CrossRef]

3. Vogel, K. Analytics of Enzymes. In Enzymes in Human and Animal Nutrition; Elsevier: Amsterdam, The Netherlands, 2018; pp. 441-455.

4. Peixoto, R.S.; Vermelho, A.B.; Rosado, A.S. Petroleum-degrading enzymes: Bioremediation and new prospects. Enzym. Res. 2011, 475193. [CrossRef] [PubMed]

5. Wang, Y.; Wang, N. Hydrolase-Catalyzed Promiscuous Reactions and Applications in Organic Synthesis. In Molecular Biotechnology; IntechOpen: London, UK, 2019; pp. 1-37.

6. Kumar, V.; Sangwan, P.; Singh, D.; Gill, P.K. Global scenario of industrial enzyme market. In Industrial Enzymes: Trends, Scope and Relevance; Nova Science Publishers: Hauppauge, NY, USA, 2014; pp. 176-196.

7. Kirk, O.; Borchert, T.V.; Fuglsang, C.C. Industrial Enzyme Applications. Curr. Opin. Biotechnol. 2002, 13, 345-351. [CrossRef]

8. Lammle, K.; Zipper, H.; Breuer, M.; Hauer, B.; Buta, C.; Brunner, H.; Rupp, S. Identification of novel enzymes with different hydrolytic activities by metagenome expression cloning. J. Biotechnol. 2007, 127, 575-592. [CrossRef]

9. Singh, R.; Kumar, M.; Mittal, A.; Mehta, P.K. Microbial Enzymes: Industrial Progress in 21st Century. 3 Biotech 2016, 6, 174. [CrossRef]

10. Fenical, W. New Pharmaceuticals from Marine Organisms. Trends Biotechnol. 1997, 15, 339-341. [CrossRef]

11. Wijffels, R.H. Potential of Sponges and Microalgae for Marine Biotechnology. Trends Biotechnol. 2008, 26, 26-31. [CrossRef]

12. Querellou, J.; Cadoret, J.-P.; Allen, M.J.; Collén, J. Marine Biotechnology. In Introduction to Marine Genomics; Springer: Dordrecht, The Netherlands, 2010; pp. 287-313.

13. Ferrer, M.; Méndez-García, C.; Bargiela, R.; Chow, J.; Alonso, S.; García-Moyano, A.; Bjerga, G.E.K.; Steen, I.H.; Schwabe, T.; Blom, C.; et al. The INMARE Consortium, Decoding the ocean's microbiological secrets for marine enzyme biodiscovery. FEMS Microbiol. Lett. 2019, 366, fny285. [CrossRef]

14. Raj, Y.; Chauhan, V.S.A. Isolation, Characterization and Screening of Novel Antibiotic Producing Bacteria from Natural Habitats of Western Himalayas and Industrial Waste Soil Samples. Int. J. Comput. Syst. 2019, 3, 3282-3288.

15. Salas-Ovilla, R.; Gálvez-López, D.; Vázquez-Ovando, A.; Salvador-Figueroa, M.; Rosas-Quijano, R. Isolation and Identification of Marine Strains of Stenotrophomona maltophilia with High Chitinolytic Activity. PeerJ 2019, 7, e6102. [CrossRef]

16. Arora, N.K.; Mishra, J.; Mishra, V. Microbial Enzymes: Roles and Applications in Industries; Springer: Singapore, 2021.

17. Singh, S.K.; Singh, M.K.; Singh, V.K.; Modi, A.; Jaiswal, P.; Rashmi, K.; Kumar, A. Microbial Enzymes and Their Exploitation in Remediation of Environmental Contaminants. In Microbe Mediated Remediation of Environmental Contaminants; Elsevier: Amsterdam, The Netherlands, 2021; pp. 59-71.

18. Illanes, A.; Cauerhff, A.; Wilson, L.; Castro, G.R. Recent Trends in Biocatalysis Engineering. Bioresour. Technol. 2012, 115, 48-57. [CrossRef]

19. Guerrand, D. Lipases Industrial Applications: Focus on Food and Agroindustries. OCL 2017, 24, D403. [CrossRef]

20. Bonugli-Santos, R.C.; dos Santos Vasconcelos, M.R.; Passarini, M.R.Z.; Vieira, G.A.L.; Lopes, V.C.P.; Mainardi, P.H.; dos Santos, J.A.; de Azevedo Duarte, L.; Otero, I.V.R.; da Silva Yoshida, A.M.; et al. Marine-Derived Fungi: Diversity of Enzymes and Biotechnological Applications. Front. Microbiol. 2015, 6, 269. [CrossRef]

21. Gomes, N.; Dasari, R.; Chandra, S.; Kiss, R.; Kornienko, A. Marine Invertebrate Metabolites with Anticancer Activities: Solutions to the "Supply Problem". Mar. Drugs 2016, 14, 98. [CrossRef]

22. Morlighem, R.L.; Huang, J.É.; Liao, C.; Braga Gomes, Q.; Daniel Pérez, P.; de Brandão Prieto-da-Silva, Á.; Ming-Yuen Lee, S.; Rádis-Baptista, G. The Holo-Transcriptome of the Zoantharian Protopalythoa variabilis (Cnidaria: Anthozoa): A Plentiful Source of Enzymes for Potential Application in Green Chemistry, Industrial and Pharmaceutical Biotechnology. Mar. Drugs 2018, 16, 207. [CrossRef]

23. Barzkar, N. Marine Microbial Alkaline Protease: An Efficient and Essential Tool for Various Industrial Applications. Int. J. Biol. Macromol. 2020, 161, 1216-1229. [CrossRef]

24. Zhang, J.; Jiang, L.; Chen, X.; Lv, K.; Basiony, M.; Zhu, G.; Karthik, L.; Ouyang, , L.; Zhang, L.; Liu, X. Recent advances in biotechnology for marine enzymes and molecules. Curr. Opin. Biotechnol. 2021, 69, 308-315. [CrossRef]

25. Tello, E.; Castellanos, L.; Arevalo-Ferro, C.; Duque, C. Cembranoid Diterpenes from the Caribbean Sea Whip Eunicea knighti. J. Nat. Prod. 2009, 72, 1595-1602. [CrossRef]

26. Mayer, A.M.S.; Glaser, K.B.; Cuevas, C.; Jacobs, R.S.; Kem, W.; Little, R.D.; McIntosh, J.M.; Newman, D.J.; Potts, B.C.; Shuster, D.E. The Odyssey of Marine Pharmaceuticals: A Current Pipeline Perspective. Trends Pharmacol. Sci. 2010, 31, 255-265. [CrossRef]

27. Mayer, A.; Rodríguez, A.; Taglialatela-Scafati, O.; Fusetani, N. Marine Pharmacology in 2009-2011: Marine Compounds with Antibacterial, Antidiabetic, Antifungal, Anti-Inflammatory, Antiprotozoal, Antituberculosis, and Antiviral Activities; Affecting the Immune and Nervous Systems, and Other Miscellaneous Mechanisms of Action. Mar. Drugs 2013, 11, 2510-2573. [CrossRef]

28. Blackall, L.L.; Wilson, B.; van Oppen, M.J.H. Coral—the World's Most Diverse Symbiotic Ecosystem. Mol. Ecol. 2015, 24, 5330-5347. [CrossRef] [PubMed] 
29. Braun, D.R.; Chevrette, M.G.; Acharya, D.; Currie, C.R.; Rajski, S.R.; Ritchie, K.B.; Bugni, T.S. Complete Genome Sequence of Dietzia sp. Strain WMMA184, a Marine Coral-Associated Bacterium. Genome Announc. 2018, 6, e01582-17. [CrossRef] [PubMed]

30. Sang, V.T.; Dat, T.T.H.; Vinh, L.B.; Cuong, L.C.V.; Oanh, P.T.T.; Ha, H.; Kim, Y.H.; Anh, H.L.T.; Yang, S.Y. Coral and CoralAssociated Microorganisms: A Prolific Source of Potential Bioactive Natural Products. Mar. Drugs 2019, 17, 468. [CrossRef] [PubMed]

31. Sweet, M.; Villela, H.; Keller-Costa, T.; Costa, R.; Romano, S.; Bourne, D.; Cardenas, A.; Huggett, M.; Kerwin, A.; Kuek, F.; et al. Insights into the Cultured Bacterial Fraction of Corals. mSystems 2020, 6, e01249-20.

32. Bosch, T.C.G.; McFall-Ngai, M.J. Metaorganisms as the New Frontier. Zoology 2011, 114, 185-190. [CrossRef]

33. Putnam, H.M.; Stat, M.; Pochon, X.; Gates, R.D. Endosymbiotic Flexibility Associates with Environmental Sensitivity in Scleractinian Corals. Proc. R. Soc. B Biol. Sci. 2012, 279, 4352-4361. [CrossRef]

34. Santoro, E.P.; Borges, R.M.; Espinoza, J.L.; Freire, M.; Messias, C.S.M.A.; Villela, H.D.M.; Pereira, L.M.; Vilela, C.L.S.; Rosado, J.G.; Cardoso, P.M.; et al. Coral Microbiome Manipulation Elicits Metabolic and Genetic Restructuring to Mitigate Heat Stress and Evade Mortality. Sci. Adv. 2021, 7, eabg3088. [CrossRef]

35. Rohwer, F.; Seguritan, V.; Azam, F.; Knowlton, N. Diversity and Distribution of Coral-Associated Bacteria. Mar. Ecol. Prog. Ser. 2002, 243, 1-10. [CrossRef]

36. Rosenberg, E.; Koren, O.; Reshef, L.; Efrony, R.; Zilber-Rosenberg, I. The Role of Microorganisms in Coral Health, Disease and Evolution. Nat. Rev. Microbiol. 2007, 5, 355-362. [CrossRef]

37. Pollock, F.J.; McMinds, R.; Smith, S.; Bourne, D.G.; Willis, B.L.; Medina, M.; Thurber, R.V.; Zaneveld, J.R. Coral-Associated Bacteria Demonstrate Phylosymbiosis and Cophylogeny. Nat. Commun. 2018, 9, 4921. [CrossRef]

38. Bourne, D.; Iida, Y.; Uthicke, S.; Smith-Keune, C. Changes in Coral-Associated Microbial Communities during a Bleaching Event. ISME J. 2007, 2, 350-363. [CrossRef]

39. Ziegler, M.; Grupstra, C.G.B.; Barreto, M.M.; Eaton, M.; BaOmar, J.; Zubier, K.; Al-Sofyani, A.; Turki, A.J.; Ormond, R.; Voolstra, C.R. Coral Bacterial Community Structure Responds to Environmental Change in a Host-Specific Manner. Nat. Commun. 2019, 10, 3092. [CrossRef]

40. Webster, N.S.; Reusch, T.B.H. Microbial Contributions to the Persistence of Coral Reefs. ISME J. 2017, 11, 2167-2174. [CrossRef]

41. Leite, D.C.; Salles, J.F.; Calderon, E.N.; Castro, C.B.; Bianchini, A.; Marques, J.A.; Van Elsas, J.D.; Peixoto, R.S. Coral bacterial-core abundance and network complexity as proxies for anthropogenic pollution. Front. Microbiol. 2018, 9, 833. [CrossRef]

42. Leite, D.C.; Leão, P.; Garrido, A.G.; Lins, U.; Santos, H.F.; Pires, D.O.; Castro, C.B.; van Elsas, J.D.; Zilberberg, C.; Rosado, A.S.; et al. Broadcast spawning coral Mussismilia hispida can vertically transfer its associated bacterial core. Front. Microbiol. 2017, 8 , 176. [CrossRef]

43. Modolon, F.; Barno, A.R.; Villela, H.D.M.; Peixoto, R.S. Ecological and Biotechnological Importance of Secondary Metabolites Produced by Coral-associated Bacteria. J. Appl. Microbiol. 2020, 129, 1441-1457. [CrossRef]

44. Villela, H.D.M.; Vilela, C.L.S.; Assis, J.M.; Varona, N.; Burke, C.; Coil, D.A.; Eisen, J.A.; Peixoto, R.S. Prospecting Microbial Strains for Bioremediation and Probiotics Development for Metaorganism Research and Preservation. J. Vis. Exp. 2019, 2019 , e60238. [CrossRef]

45. Morrow, K.M.; Moss, A.G.; Chadwick, N.E.; Liles, M.R. Bacterial Associates of Two Caribbean Coral Species Reveal SpeciesSpecific Distribution and Geographic Variability. Appl. Environ. Microbiol. 2012, 78, 6438-6449. [CrossRef]

46. Neave, M.J.; Rachmawati, R.; Xun, L.; Michell, C.T.; Bourne, D.G.; Apprill, A.; Voolstra, C.R. Differential Specificity between Closely Related Corals and Abundant Endozoicomonas Endosymbionts across Global Scales. ISME J. 2016, 11, 186-200. [CrossRef]

47. Peixoto, R.S.; Rosado, P.M.; Leite, D.C.D.A.; Rosado, A.S.; Bourne, D.G. Beneficial Microorganisms for Corals (BMC): Proposed Mechanisms for Coral Health and Resilience. Front. Microbiol. 2017, 8, 341. [CrossRef]

48. Peixoto, R.S.; Sweet, M.; Villela, H.D.; Cardoso, P.; Thomas, T.; Voolstra, C.R.; Høj, L.; Bourne, D.G. Coral probiotics: Premise, promise, prospects. Annu. Rev. Anim. Biosci. 2021, 9, 265-288. [CrossRef]

49. Silva, D.P.; Villela, H.D.; Santos, H.F.; Duarte, G.A.; Ribeiro, J.R.; Ghizelini, A.M.; Vilela, C.L.; Rosado, P.M.; Fazolato, C.S.; Santoro, E.P.; et al. Multi-domain probiotic consortium as an alternative to chemical remediation of oil spills at coral reefs and adjacent sites. Microbiome 2021, 9, 1-19. [CrossRef]

50. do Carmo, F.L.; dos Santos, H.F.; Martins, E.F.; van Elsas, J.D.; Rosado, A.S.; Peixoto, R.S. Bacterial Structure and Characterization of Plant Growth Promoting and Oil Degrading Bacteria from the Rhizospheres of Mangrove Plants. J. Microbiol. 2011, 49, 535-543. [CrossRef]

51. Santos, H.F.; Duarte, G.A.S.; da Costa Rachid, C.T.; Chaloub, R.M.; Calderon, E.N.; de Barros Marangoni, L.F.; Bianchini, A.; Nudi, A.H.; Do Carmo, F.L.; Van Elsas, J.D.; et al. Impact of oil spills on coral reefs can be reduced by bioremediation using probiotic microbiota. Sci. Rep. 2015, 5, 1-11.

52. Hoyt, J.R.; Langwig, K.E.; White, J.P.; Kaarakka, H.M.; Redell, J.A.; Parise, K.L.; Frick, W.F.; Foster, J.T.; Kilpatrick, A.M. Field trial of a probiotic bacteria to protect bats from white-nose syndrome. Sci. Rep. 2019, 9, 1-9. [CrossRef]

53. Becker, M.H.; Harris, R.N.; Minbiole, K.P.; Schwantes, C.R.; Rollins-Smith, L.A.; Reinert, L.K.; Brucker, R.M.; Domangue, R.J.; Gratwicke, B. Towards a better understanding of the use of probiotics for preventing chytridiomycosis in Panamanian golden frogs. Ecohealth 2011, 8, 501-506. [CrossRef]

54. Imhoff, J.F.; Labes, A.; Wiese, J. Bio-Mining the Microbial Treasures of the Ocean: New Natural Products. Biotechnol. Adv. 2011, 29, 468-482. [CrossRef] 
55. Radjasa, O.K.; Khoeri, M.M.; Darusallam, C.C.; Trimasanto, H.; Sudoyo, H. Bacterial Symbionts of Reef Invertebrates: Screening for Anti-Pathogenic Bacteria Activity. Biodiversity 2013, 14, 80-86. [CrossRef]

56. Rizzo, C.; Lo Giudice, A. Marine Invertebrates: Underexplored Sources of Bacteria Producing Biologically Active Molecules. Diversity 2018, 10, 52. [CrossRef]

57. El-Gendy, M.M.A. Keratinase Production by Endophytic Penicillium spp. Morsy1 Under Solid-State Fermentation Using Rice Straw. Appl. Biochem. Biotechnol. 2009, 162, 780-794. [CrossRef]

58. Bakkiyaraj, D.; Sivasankar, C.; Pandian, S.K. Anti-Pathogenic Potential of Coral Associated Bacteria Isolated from Gulf of Mannar Against Pseudomonas aeruginosa. Indian J. Microbiol. 2012, 53, 111-113. [CrossRef] [PubMed]

59. Mabrouk, M.E.; Youssif, E.M.; Sabry, S.A. Biosurfactant production by a newly isolated soft coral-associated marine Bacillus sp. E34: Statistical optimization and characterization. Life Sci. J. 2014, 11, 756-768.

60. Ahila, N.K.; Prakash, S.; Manikandan, B.; Ravindran, J.; Prabhu, N.M.; Kannapiran, E. Bio-Prospecting of Coral (Porites lutea) Mucus Associated Bacteria, Palk Bay Reefs, Southeast Coast of India. Microb. Pathog. 2017, 113, 113-123. [CrossRef] [PubMed]

61. Ledoux, J.B.; Antunes, A. Beyond the beaten path: Improving natural products bioprospecting using an eco-evolutionary framework-The case of the octocorals. Crit. Rev. Biotechnol. 2018, 38, 184-198. [CrossRef]

62. Knowlton, N.; Grottoli, A.G.; Kleypas, J.; Obura, D.; Corcoran, E.; de Goeij, J.; Felis, T.; Harding, S.; Mayfield, A.; Miller, M.; et al. Rebuilding Coral Reefs: A Decadal Grand Challenge. Int. Coral Reef Soc. Future Earth Coasts 2021, 56. [CrossRef]

63. Seoane, J.C.S.; Arantes, R.C.M.; Castro, C.B.; Tedesco, E.C.; Lopes, L.S. Atlas Físico do Parque Municipal Marinho do Recife de Fora; Projeto Coral Vivo: Rio de Janeiro, Brasil, 2008.

64. Paula, Y.C.D.; Schiavetti, A.; Sampaio, C.L.; Calderon, E. The effects of fish feeding by visitors on reef fish in a Marine Protected Area open to tourism. Biota Neotrop. 2018, 18. [CrossRef]

65. Costa Jr, O.S.; Attrill, M.J.; Pedrini, A.G.; De-Paula, J.C. Spatial and seasonal distribution of seaweeds on coral reefs from Southern Bahia, Brazil. Bot. Mar. 2002, 45, 346-355. [CrossRef]

66. Voolstra, C.R.; Quigley, K.M.; Davies, S.W.; Parkinson, J.E.; Peixoto, R.S.; Aranda, M.; Baker, A.C.; Barno, A.R.; Barshis, D.J.; Benzoni, F.; et al. Consensus guidelines for advancing coral holobiont genome and specimen voucher deposition. Front. Mar. Sci. 2021, 1029. [CrossRef]

67. Caporaso, J.G.; Lauber, C.L.; Walters, W.A.; Berg-Lyons, D.; Lozupone, C.A.; Turnbaugh, P.J.; Fierer, N.; Knight, R. Global Patterns of 16S RRNA Diversity at a Depth of Millions of Sequences per Sample. Proc. Natl. Acad. Sci. USA 2010, 108 (Suppl. 1), $4516-4522$. [CrossRef]

68. Schloss, P.D.; Westcott, S.L.; Ryabin, T.; Hall, J.R.; Hartmann, M.; Hollister, E.B.; Lesniewski, R.A.; Oakley, B.B.; Parks, D.H.; Robinson, C.J.; et al. Introducing Mothur: Open-Source, Platform-Independent, Community-Supported Software for Describing and Comparing Microbial Communities. Appl. Environ. Microbiol. 2009, 75, 7537-7541. [CrossRef]

69. Vilela, C.L.S.; Villela, H.D.M.; Duarte, G.A.; Santoro, E.P.; Rachid, C.T.; Peixoto, R.S. Estrogen induces shift in abundances of specific groups of the coral microbiome. Sci. Rep. 2021, 11, 1-10. [CrossRef]

70. Pruesse, E.; Quast, C.; Knittel, K.; Fuchs, B.M.; Ludwig, W.; Peplies, J.; Glockner, F.O. SILVA: A Comprehensive Online Resource for Quality Checked and Aligned Ribosomal RNA Sequence Data Compatible with ARB. Nucleic Acids Res. 2007, 35, 7188-7196. [CrossRef]

71. Hammer, Ø.; Harper, D.A.; Ryan, P.D. PAST: Paleontological statistics software package for education and data analysis. Palaeontol. Electron. 2001, 4, 1-9.

72. Schleif, R.F.; Wensink, P.C. Practical Methods in Molecular Biology; Springer Science \& Business Media: New York, NY, USA, 2012.

73. Hankin, L.; Zucker, M.; Sands, D.C. Improved Solid Medium for the Detection and Enumeration of Pectolytic Bacteria. Appl. Microbiol. 1971, 22, 205-209. [CrossRef]

74. Carrim, A.J.I.; Barbosa, E.C.; Vieira, J.D.G. Enzymatic activity of endophytic bacterial isolates of Jacaranda decurrens Cham. (carobinha-do-campo). Braz. Arch. Biol. Technol. 2006, 49, 353-359. [CrossRef]

75. de Castro, A.L.M.; Vollú, R.E.; Peixoto, R.S.; Grigorevski-Lima, A.L.; Coelho, R.R.R.; Bon, E.P.S.; Rosado, A.S.; Seldin, L. Cellulolytic potential of a novel strain of Paenibacillus sp. isolated from the armored catfish Parotocinclus maculicauda Gut. Braz. J. Microbiol. 2011, 42, 1608-1615. [CrossRef]

76. Hankin, L.; Anagnostakis, S.L. The Use of Solid Media for Detection of Enzyme Production by Fungi. Mycologia 1975, 67, 597. [CrossRef]

77. Williams, S.T.; Goodfellow, M.; Alderson, G.; Wellington, E.M.H.; Sneath, P.H.A.; Sackin, M.J. Numerical Classification of Streptomyces and Related Genera. Microbiology 1983, 129, 1743-1813. [CrossRef]

78. Bairagi, A.; Ghosh, K.S.; Sen, S.K.; Ray, A.K. Enzyme producing bacterial flora isolated from fish digestive tracts. Aquac. Int. 2002, 10, 109-121. [CrossRef]

79. Hsu, S.C.; Lockwood, J.L. Powdered Chitin Agar as a Selective Medium for Enumeration of Actinomycetes in Water and Soil. Appl. Microbiol. 1975, 29, 422-426. [CrossRef]

80. Chaturvedi, V.; Bhange, K.; Bhatt, R.; Verma, P. Production of keratinases using chicken feathers as substrate by a novel multifunctional strain of Pseudomonas stutzeri and its dehairing application. Biocatal. Agric. Biotechnol. 2014, 3, 167-174. [CrossRef]

81. Lane, D.J. 16S/23S rRNA sequencing. In Nucleic Acid Techniques in Bacterial Systematics; John Wiley and Sons: New York, NY, USA, 1991; pp. 115-175. 
82. Hall, T. BioEdit: A user-friendly biological sequence alignment editor and analysis program for Windows 95/98/NT. Nucleic Acids Symp. Ser. 1999, 41, 95-98.

83. Cole, J.R.; Wang, Q.; Cardenas, E.; Fish, J.; Chai, B.; Farris, R.J.; Kulam-Syed-Mohideen, A.S.; McGarrell, D.M.; Marsh, T.; Garrity, G.M.; et al. The Ribosomal Database Project: Improved Alignments and New Tools for RRNA Analysis. Nucleic Acids Res. 2009, 37, D141-D145. [CrossRef] [PubMed]

84. Thompson, J.D.; Higgins, D.G.; Gibson, T.J. CLUSTAL W: Improving the Sensitivity of Progressive Multiple Sequence Alignment through Sequence Weighting, Position-Specific Gap Penalties and Weight Matrix Choice. Nucleic Acids Res. 1994, 22, 4673-4680. [CrossRef] [PubMed]

85. Kumar, S.; Stecher, G.; Li, M.; Knyaz, C.; Tamura, K. MEGA X: Molecular Evolutionary Genetics Analysis across Computing Platforms. Mol. Biol. Evol. 2018, 35, 1547-1549. [CrossRef]

86. Stecher, G.; Tamura, K.; Kumar, S. Molecular Evolutionary Genetics Analysis (MEGA) for MacOS. Mol. Biol. Evol. 2020, 37, 1237-1239. [CrossRef]

87. Tamura, K.; Nei, M. Estimation of the Number of Nucleotide Substitutions in the Control Region of Mitochondrial DNA in Humans and Chimpanzees. Mol. Biol. Evol. 1993, 10, 512-526. [CrossRef]

88. Nakamura, K.; Iizuka, R.; Nishi, S.; Yoshida, T.; Hatada, Y.; Takaki, Y.; Iguchi, A.; Yoon, D.H.; Sekiguchi, T.; Shoji, S.; et al. Culture-Independent Method for Identification of Microbial Enzyme-Encoding Genes by Activity-Based Single-Cell Sequencing Using a Water-in-Oil Microdroplet Platform. Sci. Rep. 2016, 6, 22259. [CrossRef]

89. Vivero, R.J.; Mesa, G.B.; Robledo, S.M.; Herrera, C.X.M.; Cadavid-Restrepo, G. Enzymatic, Antimicrobial, and Leishmanicidal Bioactivity of Gram-Negative Bacteria Strains from the Midgut of Lutzomyia evansi, an Insect Vector of Leishmaniasis in Colombia. Biotechnol. Rep. 2019, 24, e00379. [CrossRef]

90. De Castro, A.P.; Araújo, S.D., Jr.; Reis, A.M.M.; Moura, R.L.; Francini-Filho, R.B.; Pappas, G., Jr.; Rodrigues, T.B.; Thompson, F.L.; Krüger, R.H. Bacterial Community Associated with Healthy and Diseased Reef Coral Mussismilia hispida from Eastern Brazil. Microb. Ecol. 2010, 59, 658-667. [CrossRef]

91. Hernandez-Agreda, A.; Gates, R.D.; Ainsworth, T.D. Defining the Core Microbiome in Corals' Microbial Soup. Trends Microbiol. 2017, 25, 125-140. [CrossRef]

92. Arotsker, L.; Siboni, N.; Ben-Dov, E.; Kramarsky-Winter, E.; Loya, Y.; Kushmaro, A. Vibrio sp. as a potentially important member of the Black Band Disease (BBD) consortium in Favia sp. corals. FEMS Microbiol. Ecol. 2009, 70, 515-524. [CrossRef]

93. Kushmaro, A.; Banin, E.; Loya, Y.; Stackebrandt, E.; Rosenberg, E. Vibrio shiloi sp. Nov., the Causative Agent of Bleaching of the Coral Oculina patagonica. Int. J. Syst. Evol. Microbiol. 2001, 51, 1383-1388. [CrossRef]

94. Sabdono, A.; Wijayanti, D.P.; Sarjito, S. Antipathogenic Activity of Bacteria Associated with Acroporid Corals Against Black Band Disease of Karimunjawa, Indonesia. Res. J. Microbiol. 2017, 12, 154-160. [CrossRef]

95. Matsumiya, Y.; Wakita, D.; Kimura, A.; Sanpa, S.; Kubo, M. Isolation and Characterization of a Lipid-Degrading Bacterium and Its Application to Lipid-Containing Wastewater Treatment. J. Biosci. Bioeng. 2007, 103, 325-330. [CrossRef]

96. Liu, X.; Ren, B.; Chen, M.; Wang, H.; Kokare, C.R.; Zhou, X.; Wang, J.; Dai, H.; Song, F.; Liu, M.; et al. Production and Characterization of a Group of Bioemulsifiers from the Marine Bacillus velezensis Strain H3. Appl. Microbiol. Biotechnol. 2010, 87, 1881-1893. [CrossRef]

97. Sabat, S.; Murthy, V.K.; Pavithra, M.; Mayur, P.; Chandavar, A. Production and characterisation of extracellular lipase from Bacillus stearothermophilus MTCC 37 under different fermentation conditions. Int. J. Eng. Res. Appl. 2012, 2, 1775-1781.

98. Mahale, P.K.; Desai, S.V.; Hombalimath, V.S.; Achappa, S. Isolation, screening and characterization of lipase producing strain from oil contaminated soil of Hubballi, Karnataka. Int. J. Basic Appl. Biol. 2014, 2, 198-201.

99. Gricajeva, A.; Bendikienė, V.; Kalèdienė, L. Lipase of Bacillus stratosphericus L1: Cloning, Expression and Characterization. Int. J. Biol. Macromol. 2016, 92, 96-104. [CrossRef]

100. Zhao, J.; Liu, S.; Gao, Y.; Ma, M.; Yan, X.; Cheng, D.; Wan, D.; Zeng, Z.; Yu, P.; Gong, D. Characterization of a novel lipase from Bacillus licheniformis NCU CS-5 for applications in detergent industry and biodegradation of 2, 4-D butyl ester. Int. J. Biol. Macromol. 2021, 176, 126-136. [CrossRef]

101. Khunt, M.; Pandhi, N.; Rana, A. Media Optimization for Lipase from Halomonas salina Mk-23, Moderate Halophiles Isolated from Wild Ass Excreta. J. Pure Appl. Microbiol. 2012, 6, 845-850.

102. Li, C.-Y.; Cheng, C.-Y.; Chen, T.-L. Fed-Batch Production of Lipase by Acinetobacter radioresistens Using Tween 80 as the Carbon Source. Biochem. Eng. J. 2004, 19, 25-31. [CrossRef]

103. Li, C.-Y.; Chen, S.-J.; Cheng, C.-Y.; Chen, T.-L. Production of Acinetobacter radioresistens Lipase with Repeated Fed-Batch Culture. Biochem. Eng. J. 2005, 25, 195-199. [CrossRef]

104. Javed, S.; Azeem, F.; Hussain, S.; Rasul, I.; Siddique, M.H.; Riaz, M.; Afzal, M.; Kouser, A.; Nadeem, H. Bacterial Lipases: A Review on Purification and Characterization. Prog. Biophys. Mol. Biol. 2018, 132, 23-34. [CrossRef]

105. Patel, R.K.; Shah, R.K.; Prajapati, V.S.; Patel, K.C.; Trivedi, U.B. Draft Genome Analysis of Acinetobacter indicus Strain UBT1, an Efficient Lipase and Biosurfactant Producer. Curr. Microbiol. 2021, 78, 1238-1244. [CrossRef]

106. Phukon, L.C.; Chourasia, R.; Kumari, M.; Godan, T.K.; Sahoo, D.; Parameswaran, B.; Rai, A.K. Production and characterisation of lipase for application in detergent industry from a novel Pseudomonas helmanticensis HS6. Bioresour. Technol. 2020, $309,123352$. [CrossRef] 
107. Sarmah, N.; Revathi, D.; Sheelu, G.; Yamuna Rani, K.; Sridhar, S.; Mehtab, V.; Sumana, C. Recent advances on sources and industrial applications of lipases. Biotechnol. Prog. 2018, 34, 5-28. [CrossRef]

108. Filho, D.G.; Silva, A.G.; Guidini, C.Z. Lipases: Sources, Immobilization Methods, and Industrial Applications. Appl. Microbiol. Biotechnol. 2019, 103, 7399-7423. [CrossRef]

109. Nielsen, T. Industrial Application Possibilities for Lipase. Fette Seifen Anstrichm. 1985, 87, 15-19. [CrossRef]

110. Navvabi, A.; Razzaghi, M.; Fernandes, P.; Karami, L.; Homaei, A. Novel Lipases Discovery Specifically from Marine Organisms for Industrial Production and Practical Applications. Process. Biochem. 2018, 70, 61-70. [CrossRef]

111. Kiran, G.S.; Shanmughapriya, S.; Jayalakshmi, J.; Selvin, J.; Gandhimathi, R.; Sivaramakrishnan, S.; Arunkumar, M.; Thangavelu, T.; Natarajaseenivasan, K. Optimization of Extracellular Psychrophilic Alkaline Lipase Produced by Marine Pseudomonas sp. (MSI057). Bioprocess. Biosyst. Eng. 2008, 31, 483-492. [CrossRef]

112. Hassan, S.W.M.; Abd El Latif, H.H.; Ali, S.M. Production of Cold-Active Lipase by Free and Immobilized Marine Bacillus cereus HSS: Application in Wastewater Treatment. Front. Microbiol. 2018, 9, 2377. [CrossRef]

113. Verma, S.; Meghwanshi, G.K.; Kumar, R. Current perspectives for microbial lipases from extremophiles and metagenomics. Biochimie 2021, 182, 26-36. [CrossRef]

114. Gupta, R.; Beg, Q.K.; Lorenz, P. Bacterial Alkaline Proteases: Molecular Approaches and Industrial Applications. Appl. Microbiol. Biotechnol. 2002, 59, 15-32. [CrossRef]

115. Hammami, A.; Hamdi, M.; Abdelhedi, O.; Jridi, M.; Nasri, M.; Bayoudh, A. Surfactant- and Oxidant-Stable Alkaline Proteases from Bacillus invictae: Characterization and Potential Applications in Chitin Extraction and as a Detergent Additive. Int. J. Biol. Macromol. 2017, 96, 272-281. [CrossRef]

116. Thakur, N.; Goyal, M.; Sharma, S.; Kumar, D. Proteases: Industrial applications and approaches used in strain improvement. Biol. Forum-An. Int. J. 2018, 10, 158-167.

117. Barzkar, N.; Homaei, A.; Hemmati, R.; Patel, S. Thermostable Marine Microbial Proteases for Industrial Applications: Scopes and Risks. Extremophiles 2018, 22, 335-346. [CrossRef]

118. Vojcic, L.; Jakob, F.; Martinez, R.; Hellmuth, H.; O'Connell, T.; Mühl, H.; Lorenz, M.G.; Schwaneberg, U. Engineering Proteases for Industrial Applications. In Applied Biocatalysis: From Fundamental Science to Industrial Applications; Wiley-VCH Verlag GmbH \& Co. KGaA: Weinheim, Germany, 2016; pp. 101-119.

119. Suriya, J.; Bharathiraja, S.; Krishnan, M.; Manivasagan, P.; Kim, S.-K. Extremozymes from Marine Actinobacteria. In Marine Enzymes Biotechnology: Production and Industrial Applications, Part II-Marine Organisms Producing Enzymes; Elsevier: Amsterdam, The Netherlands, 2016; pp. 43-66.

120. Hamza, H.M.; Ali, S.M.; Hassan, H.G. Partial purification of gelatinase enzyme from local isolate of Brevibacillus laterosporus. Natl. J. 2006, 23, 437-442.

121. Sameena, F.M.; Radha, P. Fish Waste Gelatin: A Renewable Substrate for Production of Gelatinase by Serratia Marcescens MF599353. J. Solid Waste Technol. Manag. 2020, 46, 168-177. [CrossRef]

122. Sai-Ut, S.; Benjakul, S.; Sumpavapol, P. Gelatinolytic Enzymes from Bacillus amyloliquefaciens Isolated from Fish Docks: Characteristics and Hydrolytic Activity. Food Sci. Biotechnol. 2013, 22, 1015-1021. [CrossRef]

123. Yuivar, Y.; Alcaino, J.; Cifuentes, V.; Baeza, M. Characterization of Gelatinase Produced by Antarctic mrakia sp. J. Basic Microbiol. 2019, 59, 846-852. [CrossRef]

124. Chimetto, L.A.; Cleenwerck, I.; Thompson, C.C.; Brocchi, M.; Willems, A.; De Vos, P.; Thompson, F.L. Photobacterium jeanii sp. nov., Isolated from Corals and Zoanthids. Int. J. Syst. Evol. Microbiol. 2010, 60, 2843-2848. [CrossRef]

125. Yoshizawa, S.; Tsuruya, Y.; Fukui, Y.; Sawabe, T.; Yokota, A.; Kogure, K.; Higgins, M.; Carson, J.; Thompson, F.L. Vibrio jasicida sp. nov., a Member of the Harveyi Clade, Isolated from Marine Animals (Packhorse Lobster, Abalone and Atlantic Salmon). Int. J. Syst. Evol. Microbiol. 2012, 62 Pt 8, 1864-1870. [CrossRef]

126. Ramlath, L.; Keerthana, P.P.; Safvana Fathima, P.; Mashhoor, K. Bacteria from Coral Ecosystem of Kiltan Island, Lakshadweep: Resource for Hydrolytic Enzymes. Int. J. Cell Sci. Biotechnol. 2018, 7, 1-9.

127. Ben-Haim, Y.; Thompson, F.L.; Thompson, C.C.; Cnockaert, M.C.; Hoste, B.; Swings, J.; Rosenberg, E. Vibrio coralliilyticus sp. nov., a Temperature-Dependent Pathogen of the Coral Pocillopora damicornis. Int. J. Syst. Evol. Microbiol. 2003, 53, 309-315. [CrossRef]

128. Thompson, F.L.; Barash, Y.; Sawabe, T.; Sharon, G.; Swings, J.; Rosenberg, E. Thalassomonas loyana sp. nov., a Causative Agent of the White Plague-like Disease of Corals on the Eilat Coral Reef. Int. J. Syst. Evol. Microbiol. 2006, 56, 365-368. [CrossRef]

129. Stetler-Stevenson, W.G.; Aznavoorian, S.; Liotta, L.A. Tumor Cell Interactions with the Extracellular Matrix During Invasion and Metastasis. Annu. Rev. Cell Biol. 1993, 9, 541-573. [CrossRef]

130. Balan, S.S.; Nethaji, R.; Sankar, S.; Jayalakshmi, S. Production of Gelatinase Enzyme from Bacillus Spp Isolated from the Sediment Sample of Porto Novo Coastal Sites. Asian Pac. J. Trop. Biomed. 2012, 2, S1811-S1816. [CrossRef]

131. Wang, Q.; Liu, F.; Wang, L.; Xie, C.; Wu, P.; Du, S.; Zhou, S.; Sun, Z.; Liu, Q.; Yu, L.; et al. Enhanced and Prolonged Antitumor Effect of Salinomycin-Loaded Gelatinase-Responsive Nanoparticles via Targeted Drug Delivery and Inhibition of Cervical Cancer Stem Cells. Int. J. Nanomed. 2020, 15, 1283-1295. [CrossRef]

132. Mohan, R.; Chintala, S.K.; Jung, J.C.; Villar, W.V.L.; McCabe, F.; Russo, L.A.; Lee, Y.; McCarthy, B.E.; Wollenberg, K.R.; Jester, J.V.; et al. Matrix Metalloproteinase Gelatinase B (MMP-9) Coordinates and Effects Epithelial Regeneration. J. Biol. Chem. 2002, 277, 2065-2072. [CrossRef] 
133. Shulga, A.P.; Lamash, N.E. Proteinases with gelatinase activity and their role in ambulacrum regeneration in holothurians Eupentacta fraudatrix (D'yakonov and Baranova, 1958) and Cucumaria japonica (Semper, 1868) (Echinodermata: Holothuroidea). Russ. J. Mar. Biol. 2020, 46, 461-471. [CrossRef]

134. Robyt, J.F.; Ackerman, R.J. Isolation, Purification, and Characterization of a Maltotetraose-Producing Amylase from Pseudomonas stutzeri. Arch. Biochem. Biophys. 1971, 145, 105-114. [CrossRef]

135. Dutta, P.; Deb, A.; Majumdar, S. Optimization of the Medium for the Production of Extracellular Amylase by The Pseudomonas stutzeri ISL B5 Isolated from Municipal Solid Waste. Int. J. Microbiol. 2016, 2016, 1-7. [CrossRef] [PubMed]

136. Zhang, Z.; Jin, T.; Xie, X.; Ban, X.; Li, C.; Hong, Y.; Cheng, L.; Gu, Z.; Li, Z. Structure of Maltotetraose-Forming Amylase from Pseudomonas saccharophila STB07 Provides Insights into Its Product Specificity. Int. J. Biol. Macromol. 2020, 154, 1303-1313. [CrossRef]

137. Safari, M.; Kari Dolatabad, H.; Ndu, U.; Rivera, N.A. Protective Effect of Pseudomonas Spp. Isolates and Zinc on Seed Germination and $\beta$-Amylase Activity in Wheat Cultivars under Cadmium Stress. Acta Physiol. Plant. 2020, 42, 1-10. [CrossRef]

138. Rosado, P.M.; Leite, D.C.A.; Duarte, G.A.S.; Chaloub, R.M.; Jospin, G.; Nunes da Rocha, U.; Saraiva, J.P.; Dini-Andreote, F.; Eisen, J.A.; Bourne, D.G.; et al. Marine Probiotics: Increasing Coral Resistance to Bleaching through Microbiome Manipulation. ISME J. 2018, 13, 921-936. [CrossRef]

139. Douglas, N.L.; Mullen, K.M.; Talmage, S.C.; Harvell, C.D. Exploring the Role of Chitinolytic Enzymes in the Sea Fan Coral, Gorgonia ventalina. Mar. Biol. 2006, 150, 1137-1144. [CrossRef]

140. Kumar, M.N.R. A review of chitin and chitosan applications. React. Funct. Polym. 2000, 46, 1-27. [CrossRef]

141. Rinaudo, M. Chitin and chitosan: Properties and applications. Prog. Polym. Sci. 2006, 31, 603-632. [CrossRef]

142. Stoykov, Y.M.; Pavlov, A.I.; Krastanov, A.I. Chitinase Biotechnology: Production, Purification, and Application. Eng. Life Sci. 2014, 15, 30-38. [CrossRef]

143. Nayak, S.K.; Nayak, S.; Mohanty, S.; Sundaray, J.K.; Mishra, B.B. Microbial Chitinases and Their Applications: An Overview. In Environmental and Agricultural Microbiology: Applications for Sustainability; Wiley: Hoboken, NJ, USA, 2021; pp. 313-340.

144. Yoshioka, Y.; Tanabe, T.; Iguchi, A. The Presence of Genes Encoding Enzymes That Digest Carbohydrates in Coral Genomes and Analysis of Their Activities. PeerJ 2017, 5, e4087. [CrossRef]

145. Brandelli, A. Bacterial Keratinases: Useful Enzymes for Bioprocessing Agroindustrial Wastes and Beyond. Food Bioprocess. Technol. 2007, 1, 105-116. [CrossRef]

146. Nnolim, N.E.; Udenigwe, C.C.; Okoh, A.I.; Nwodo, U.U. Microbial keratinase: Next generation green catalyst and prospective applications. Front. Microbiol. 2020, 11, 3280. [CrossRef]

147. Hassan, M.A.; Abol-Fotouh, D.; Omer, A.M.; Tamer, T.M.; Abbas, E. Comprehensive insights into microbial keratinases and their implication in various biotechnological and industrial sectors: A review. Int. J. Biol. Macromol. 2020, 154, 567-583. [CrossRef]

148. Brandelli, A.; Daroit, D.J.; Riffel, A. Biochemical Features of Microbial Keratinases and Their Production and Applications. Appl. Microbiol. Biotechnol. 2009, 85, 1735-1750. [CrossRef]

149. Lin, X.; Lee, C.-G.; Casale, E.S.; Shih, J.C.H. Purification and Characterization of a Keratinase from a Feather-Degrading Bacillus licheniformis Strain. Appl. Environ. Microbiol. 1992, 58, 3271-3275. [CrossRef]

150. Herzog, B.; Overy, D.P.; Haltli, B.; Kerr, R.G. Discovery of Keratinases Using Bacteria Isolated from Marine Environments. Syst. Appl. Microbiol. 2016, 39, 49-57. [CrossRef]

151. Arokiyaraj, S.; Varghese, R.; Ali Ahmed, B.; Duraipandiyan, V.; Al-Dhabi, N.A. Optimizing the Fermentation Conditions and Enhanced Production of Keratinase from Bacillus cereus Isolated from Halophilic Environment. Saudi J. Biol. Sci. 2019, 26, 378-381. [CrossRef]

152. Bhange, K.; Chaturvedi, V.; Bhatt, R. Potential Biofilm Dispersal by a Partially Purified Keratinase Produced by Stenotrophomonas maltophilia Strain Kb2. Biocatal. Agric. Biotechnol. 2015, 4, 801-805. [CrossRef]

153. Steinert, G.; Whitfield, S.; Taylor, M.W.; Thoms, C.; Schupp, P.J. Application of Diffusion Growth Chambers for the Cultivation of Marine Sponge-Associated Bacteria. Mar. Biotechnol. 2014, 16, 594-603. [CrossRef]

154. Berdy, B.; Spoering, A.L.; Ling, L.L.; Epstein, S.S. In Situ Cultivation of Previously Uncultivable Microorganisms Using the Ichip. Nat. Protoc. 2017, 12, 2232-2242. [CrossRef]

155. Palma Esposito, F.; Ingham, C.J.; Hurtado-Ortiz, R.; Bizet, C.; Tasdemir, D.; de Pascale, D. Isolation by Miniaturized Culture Chip of an Antarctic Bacterium Aequorivita Sp. with Antimicrobial and Anthelmintic Activity. Biotechnol. Rep. 2018, 20 , e00281. [CrossRef]

156. MacIntyre, L.W.; Haltli, B.A.; Kerr, R.G. Draft Genome Sequence of Alteromonas sp. Strain RKMC-009, Isolated from Xestospongia muta via In Situ Culturing Using an Isolation Chip Diffusion Chamber. Microbiol. Resour. Announc. 2019, 8, e00508-19. [CrossRef]

157. Peixoto, R.S.; Sweet, M.; Bourne, D.G. Customized Medicine for Corals. Front. Mar. Sci. 2019, 6, 686. [CrossRef] 